\title{
Degradation, restitution and the elusive culture of rural-urban thinking
}

\author{
MIREK DYMITROW
}

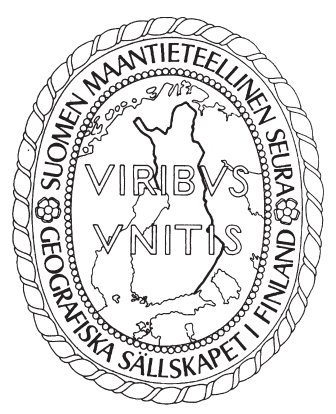

Dymitrow, Mirek (2017). Degradation, restitution and the elusive culture of rural-urban thinking. Fennia 195: 1, pp. 36-60. ISSN 1798-5617.

$\boldsymbol{\nabla}$ Despite fierce criticisms, 'rural' and 'urban' still constitute powerful narratives around which we structure our society. The 'formal reality', however, frequently disregards the cultural nature of these concepts, elevating them to the role of objective spaces apt to serve as acceptable guiding perspectives. While the analytical inadequacy of rural-urban ideations is well-documented, the phenomenon of formal-cultural conflation remains much less explored. Acknowledging that ideational space of social representations can only exist through the practices of discursive interaction, this paper's objective is to lay bare the phenomenon of rural-urban thinking when externalized through the little-known practices of 'degradation' and 'restitution' in Poland. Using conceptual methods, including discourse analysis and historical deconstruction, this paper assays the hidden architectures of formal-cultural conflation by means of a richly contextualized analysis. The findings, presented in four discursive openings, reveal embedded elements of hierarchy, loss, injustice and self-victimization, which may create a divisive culture spawned by elusive promises of development at the cost of misinterpretations of history, local disappointment and cultural segmentation. In conclusion, formal appropriation of historical concepts is likely to engender a cultural geography of discord spun around a largely insignificant division, especially when development-oriented aspects of urbanization become entwined with emotional issues.

Keywords: rural-urban, cultural-formal, degradation, restitution, discourse analysis, Poland

Mirek Dymitrow, Department of Economy and Society, Human Geography Unit, School of Business, Economics and Law, University of Gothenburg, P.O. Box 630; SE-405 30 Göteborg, Sweden, E-mail: mirek.dymitrow@geography.gu.se

\section{Introduction}

With Poland as an example, this paper aims to lay bare the phenomenon of rural-urban thinking when externalized through the little-known practices of 'degradation' and 'restitution'. As scholarly evidence suggests, the concepts 'rural' and 'urban' are increasingly treated as a pair of social constructs rather than as sets of geographically bounded places or facticities (Champion \& Hugo 2004; Cloke 2006a; Halfacree 2006; Scott et al. 2007; Hubbard 2006; Woods 2010a; Bosworth \& Somerville 2014). Steady, fast-paced transformations in the environmental, economic and social dimensions (cf. Millward et al. 2003) have rendered simple spatial classifications inadequate to social theory, especially when rooted 
in a centuries-long dichotomous imaginary that defies contemporary reality of interconnectedness (Hoggart 1990; Halfacree 1993; Little 1999; Pile 1999). When external conditions change, older conceptualizations are usually being questioned (Jones 2009); the rural-urban dichotomy, however, is one discursive standard that has withstood similar devolution and is more and more in need of critical analysis (cf. Dymitrow \& Stenseke 2016). To reflect this, the last decades have embraced nonessentialist approaches (including actor-network theory, assemblage philosophy, performativity, more-than-human approaches etc.) that eschew notions of a coherent social totality and of various conceptual binaries like human-nonhuman, modern-unmodern, material-immaterial, naturalcultural, or, indeed, rural-urban (Law \& Urry 2004; Braun 2005; Bennett \& Joyce 2010; Castree et al. 2010; Panelli 2010; Anderson et al. 2012; Latour 2013; Dahlberg 2015; Bawaka Country et al. 2016). This erasure has provided a foundation for more creative combinations that embrace relationality and hybridity more timely ways to approach and understand various concepts (cf. Murdoch 2003; Cloke \& Johnston 2005; Leyshon 2008; Halfacree 2009a; Woods 2010b; Bukraba-Rylska \& Burszta 2011; Gorman-Murray et al. 2012; Dymitrow \& Stenseke 2016).

This position, however, has not been equally adopted worldwide. In line with the notion that "ideational space of social representations can only exist through the practices of discur-sive interaction" (Halfacree 2006, 48), different countries have developed different understandings of the universal rural-urban distinction (Mihaylov 2014), leading up to intricate patterns of societal organization (Hall 1997; Halfacree 2009b). Accordingly, half of the world's countries use administrative definitions of "urban", 51 use size/density, 39 use functional characteristics, 22 have no such definition, while eight define all or none of their population as "urban" (Vlahov \& Galea 2002, 52). Different countries have also very different official definitions of "rural areas", ranging from population dispersion to agricultural-based economy, distance from major urban centers, or lack of access to various services (European Commission 2008). While formalization of domestic understandings of 'rural' and 'urban' are implicitly "cultural", i.e. they are in one way or another thought to reflect the local context - geographies, customs, practices - there are several obstacles standing in the way of obtaining a satisfactory cultural-formal symmetry. Here I will only touch upon three: institutional inertia, imposition of standards and ulterior motives.

The first problem lies in the fact that the society evolves faster than do institutional structures (Kegan \& Lahey 2009). Institutional lock-ins, hence, may be detrimental to society, because not only may old structures no longer reciprocate with a changing world but the concepts upon which those structures are based often give rise to new ill-devised structures (cf. Essebo 2013). Secondly, formal representations of 'rural/urban' may sometimes poorly, if not at all, reflect the local context because of complex histories of occupation, annexation and colonialism, whereupon imposed systems of governance may continue to be cultivated after independence (Schaffer 1978). Lastly, formal representations are often "expressed by capitalist interests or politicians, which refer to the ways in which the rural [or urban] is framed within capitalist processes of production and exchange" (Halfacree $2006,51)$, and may have little in common with the real needs of the citizens. While problems inherent of formal-cultural disruption can be found in most countries (cf. Szymańska 2013, appendix), they are likely to be the greatest when all of the aforementioned factors interplay. Expectedly, in those cultural settings where 'rural' and 'urban' have historically come to comprise more powerful narratives and conversational realities, they are less likely to be used as neutral classifiers but as expressions of old value systems that have "survived the onslaught of material transformations and philosophical repositioning" (Cloke \& Johnston 2005, 10). However, while uncovering the causes behind such conflations often requires going back in history (Gorlach \& Foryś 2003), those largely historical factors typically remain hidden when 'rural/urban' imaginaries are allowed to shape contemporary geographies.

Since 'rural/urban' are seen foremost as historically shaped spatialities (Bosworth \& Somerville 2014,278 ), they are likely to become a much overused lens in those contexts (planning, governance, research) which adopt spatially based, rather than problem-based, categorizations for various societal actions. This mode of knowledge production brings forth questions of how spatial characterizations not only create spatialities ('rural' and 'urban' areas) but spatialities with "expected" problems. When spatial perspectivism - the repeated resorting to synthetic 'foreground perspective-optics' (Nietzsche [1878] 1996) - is applied a priori to various societal problems, it is likely to distort the results (cf. Law 
2004, 5-6). Hence, while 'spatial thinking' is not limited to 'rural-urban thinking', the mere act of deploying a spatial analysis in certain contexts may be problematic because many phenomena, like deprivation, unemployment or discrimination, occur independently of some overarching spatial matrix. This in turn creates geosophical environments (Wright 1947) under the guise of geographic demarcation. What this does is create tacit acknowledgment of the importance of the spatial dimension, when no (or little) such importance is warranted and may smack of the much critiqued spatial fetishism. This then may tacitly reaffirm their implied neutrality and provide justification for governmental bodies, policy makers and planners to use 'rural/urban' as if they were spatially neutral categories (cf. Hoggart 1990). Effectively, when culture is conflated with normative perspectives the outcome becomes internalized as objective truths, which may consolidate an image that is largely disingenuous to a changed reality (cf. Freibach-Heifetz \& Stopler 2008).

Similar reflexivity regarding the articulation of rural-urban ideations is disconcertingly absent in Poland (cf. Wójcik 2013; Krzysztofik \& Dymitrow 2015a). There, "becoming urban" is considered an exclusive achievement, one that can only be accomplished by a convoluted and heavily bureaucratized process, which may or may not lead to the desired effect (cf. Dymitrow 2013; Szmytkie 2015). At the same time, any area without urban status is automatically and relentlessly regarded rural. Given that Poland has not been exempt from sundry urbanization processes that have been going on for decades, such understanding of rurality strikes as vestigial. Unfortunately, it both reflects and affects ways in which policy, planning and research on rural-urban issues in Poland are done (Gorlach \& Foryś 2003; Bukraba-Rylska \& Burszta 2011). When preconceived ideas about how issues associated with certain (labeled) spatialities ought to be handled are allowed to serve as guiding lights, obtaining development goals can prove problematic - if not unachievable (Dymitrow \& Brauer 2016). This is especially true for areas whose anticipated socio-spatial balance, the expected compatibility between conceptualizations of space and the characteristics of that space, is disrupted because of the uneven pace of urbanization observed across different geographical contexts (cf. Easterlin et al. 2011).

While Poland offers a research-friendly setting for watching rural-urban relations 'in the making', it is, of course, not an exception. Although particularly viable in countries where a rural-urban distinction finds political reflection (Krzysztofik et al. 2016), the universality of rural-urban thinking may make problems inherent of rural-urban labeling surface regardless of whether the national rural-urban distinction is political, statistical or both. To uncover these relations, discourse analysis has been used in various culture-spanning geographical studies predicated on exposing hidden structures embedded in various rural-urban portrayals (Lees 2004; Erjavec \& Erjavec 2007; Barnes \& Duncan 2013; Almstedt et al. 2014; Dymitrow \& Brauer 2014). However, since 'rural-urban thinking' (due to its proliferation across many societal domains) is likely to create deep-seated cultural geographies (Soja \& Hooper 1993), its rationale may at times be difficult to penetrate. Hence, in order to bring new perspectives to the 'rural-urban problem' in general, and - in particular - to those cultural settings where spatial conceptualizations appear to have reached a standstill, the challenge, so it seems, lies in the ability to fuse theoretical frameworks with various syntactic techniques to help make notable moves towards new modes of knowledge-making (cf. Franklin \& Crang 2001).

Previous studies adopting a fusional approach have brought forth innovative perspectives on 'rurality' and 'urbanity' by means of auxiliary conceptual lenses (Hubbard et al. 2002), i.e. alternative, secondary or derivative ideas (relative to the main one) that can "help put into a new and clearer perspective several aspects of the role which auxiliary concepts play in scientific theories" (Hintikka \& Tuomela 1970, 298). Using such an approach, a number of hidden paradoxes inherent of 'ruralurban thinking' have been uncovered or at least made more apparent. For instance, discourses of the 'rural idyll' in England have been shown to overshadow rurality's complexity to the point of denying it 'deprivation' (Woodward 1996); constructions of American poor in 'rural areas' as deviant and failing - to obscure failures of pro-market policies (Lawson et al. 2008); while the Soviet legacy of 'collective culture' in Russia - to construct a rurality that ignores the increasing role of individualization (Shubin 2007). Other fusional approaches using auxiliary concepts have been successful in tying together rurality/urbanity with e.g. race (Cloke 2006b), gender roles (Bryant \& Pini 2010; Stenbacka 2011), popular fiction (Eriksson 2010), 'nature' (Saltzman et al. 2011), religion (Bereton et al. 2011) or 
sexuality (Williams et al. 2005). Their successfulness lies in their ability to supersede conceptual inertias upheld by the ilk of forces such as cognitive internalization, political correctness or cultural taboos (cf. Rapport \& Overing 2014).

In this sense, the auxiliary concepts of degradation and restitution explored in this paper can add depth and context to what lies at the heart of rural-urban thinking in contemporary Poland. Seeing degradation and restitution as cultural spectra of the "rural-urban welter" (see Dewey 1960, 63), the aim of this paper is to enrich geographers' understanding of 'rural/urban' in the conceptual dimension through a richly contextualized account of the ubiquitous yet little-known practices of degradation and restitution'. Seen more broadly in the tradition of discourse-analytical contributions to rural and urban studies, this paper pinpoints the ambiguity and contentiousness of 'rural/urban' as cultural concepts when elevated to formalization (cf. Haack 1996). Moreover, given that engagement with the constructions of rurality/urbanity in contemporary research has been based predominantly on Anglo-Saxon accounts from north-western Europe and the United States (cf. Kurtz \& Craig 2009; Johnston \& Sidaway 2015), a Polish experience adds geographical breadth to the subject matter.

\section{Methodology and materials}

Departing form a critical-theory outlook on knowledge production, this paper adopts a historicalrealism ontology (what is seen as 'real' has been shaped by social, political, cultural, economic, and other values) of rural-urban realities, which, while inaccurately considered 'true', are essentially 'real' now (cf. Lincoln et al. 2011). As such, the paper analyzes the current situation in Poland shaped by references to, rather than an investigation into, a 'historical reality'. The epistemology of critical theory involves forms of transactionalism and subjectivism, while the associated methodology typically discovers findings through the exchange of logical arguments that "transform ignorance and misapprehensions (accepting historically mediated structures as immutable) into more informed consciousness" (Guba \& Lincoln 1994, 110). Seeing 'rural/urban' as such structures, this paper is crafted as a conceptual - not an empirical - one. 'Conceptual research', nominally, is the opposite of 'empirical research' as it "seeks to undertake a logical clarification of concepts and analysis of the use of a con-cept" (Xin et al. 2013, 72). Conceptual research is primarily concerned with what is being put into the concept purported to explain a particular phenomenon, by combining theory with more general empirical insights and philosophical commitments (cf. Maxwell 2013). As Tribe and Liburd $(2016,45)$ contend, "the authors' expertise, long term engagement with the issues and deep knowledge of the relevant literature", rather than the systematic evaluation of empirical materials (cf. LeuzingerBohleber 2004). Hence, while drawing on and combining insights from extensive empirical work, the focus of this paper is on philosophical analysis of the central findings common to much of the underlying empirical material.

The employed methodology followed a two-step research process. The first part was concerned with exploring discursive patterns in and across sought-out statements, while in the second part a critical evaluation of the identified discourses was carried out.

Given that assertions about 'rural/urban' are always based on subjective characterizations implicated in the discursive production of places (Cresswell 2004; Woods 2010a), the first step (not addressed explicitly in this paper) was to identify the dominant discourses shaping rural-urban attitudes in Poland today. For this part, discourse analysis was employed, a method "naturally embedded within Critical Theory" (Hidalgo Tenorio 2011, 187). This was done by searching for key words and phrases in Polish, such as "degraded town", "urban degradation", "restituted town" "urban restitution", "urban status", "town privileges", "forfeiting urban status", "regaining urban status", "rural to urban", "urban to rural" etc., and singling out materials according to their source of origin. Next, whole texts or relevant chunks of texts were read for context, situatedness and cues of intertextuality with regard to how common-sense understandings of statements regarding degradation/restitution are accepted and articulated as 'true' or 'naturalized'.

In line with the paper's philosophical ambition, it was necessary to take into account a material that was broad enough to warrant ample synthetization. This was done by investigating the discursive 
mindsets suffusing three major societal layers related to the topic of degradation/restitution in Poland: a) the political arena, b) the academic community and c) "lay people".

(a) Political attitudes were examined by studying all available governmental projects of decrees, and the associated justifications, of the Council of Ministers (of the Polish Ministry of Interior and Administration) regarding granting urban status to rural settlements, issued between 2003 and 2016; such materials were not published officially prior to 2003. For the same years, additional materials associated with these decrees, i.e. for the particular settlements under evaluation, were also examined, mostly petitions, appeals, recommendations and declarations, issued by local and regional administrations (county councils and municipal governments). These materials are time-specific as they cover concrete episodes of prospective restitution along with associated instantiations thereof by recourse to degradation. Examples:

This application for urban status on behalf of the settlement of Radoszyce is based first and foremost on historical factors. Radoszyce was a city for over 500 years. In 1869 its town privileges were removed by a Czarist law, which was a punishment for the residents' involvement in the January Uprising (Radoszyce Municipality 2016; my translation).

Among evidence for a positive evaluation of this application [for urban status] should be noted the following arguments and circumstances: a) infrastructural/spatial: (...) Zakliczyn has a classic market square and a clearly demarcated center with compact small-town architecture (...) b) historical: first mentions of Zakliczyn are from the 9th/10th century; Zakliczyn had town privileges in the years 1557-1934 (Council of Ministers of the Republic of Poland 2005; my translation).

(b) Attitudes in scientific approaches were synthesized by covering most of the existing literature on degradation/restitution set out to capture its state-of-the-art. Most of these works (over 50), including a recent comprehensive editorial endeavor (Krzysztofik \& Dymitrow 2015a), are cited throughout this paper. The focus is on conceptualizations of degradation/restitution after the fall of Communism in Poland in 1989, i.e. when initiatives for restitution were allowed to emerge from the local governments, and particularly after 2000, when current discourses became consolidated (cf. Dymitrow 2013). Due to their nature, these materials tend to be synthesizing and generalizing longer historical periods. Examples:

[Degraded towns] are part of [Polish] history, heritage and culture. They constitute a specific element within Poland's spatial economic structure. They are also an integral part of the country's settlement system, a component unknown of in other European countries. They linger in Poland's local tradition, and, in spite of many historical storms, they have managed to survive in oblivion. They are a testimony of foreign violence, old injustice and present incomprehension (...) (Siemiński 2000, 14; my translation).

The most radical changes in urban structure were introduced by the Russian government in the Kingdom of Poland: 338 of 452 cities were degraded (75\%). The regulations were introduced after the fall of the January Uprising. It was one of many repressions which followed the uprising. The loss of urban status was connected with many social and economic problems imposed on the citizens of degraded cities (...) (Miszewska 2007, 36).

(c) Perspectives of locals were analyzed using mainly web-based materials associated with the subject of degradation/restitution: social media, blog threads, articles covering the local voices, as well as online comments to those articles. Important sources of information were websites of local interest groups, cultural associations and opining individuals. Due to their unofficial nature, these sources tend to be more spontaneous and colloquial but often emerge alongside a prospective restitution, either official or in-the-making, of the home town or a nearby town. The information was juxtaposed with overarching discursive patterns found in personal, sporadic conversations with residents made during past field visits (2010-2016) to c. 160 degraded and restituted towns. These trips were part of research concerned with evaluating the morphological basis for the studied towns, cf. Dymitrow (2012, 2013, 2014, 2015; Krzysztofik \& Dymitrow 2015b). The overall time frame for lay sources is 2010-2017, with particular focus on the most recent cases. Examples:

[Interview with a resident of Widuchowa:] Our settlement has been a city for years; I don't understand why we today are treated as a village (...). We want to address the local municipal authorities to do something about it (Remont 2016; my translation). 
[Interview with a resident of Opatówek:] I am very happy that our efforts did not go to waste (...). For almost six centuries, until year 1870, Opatówek was a city. It lost town privileges by means of a Czarist decree as a consequence of the repercussion following the January Uprising. Now, after 150 years, it can regain its former status (Bielewicz 2016; my translation).

For the purposes of this paper, that is "a more abstract mapping of the discourses that circulate in society at a particular mo-ment in time or within a specific social domain" (Winther Jørgensen \& Phillips 2002, 20), the focus of analysis was less on the differences between these dimensions, which were surprisingly few and insignificant, but on the many context-bound and occasioned similarities, which conspicuously overlay each other to eventually consolidate a national psyche of specific attitudes (cf. Pennebaker \& Banasik [1997] 2008). During this step, the following four dominant discourses were identified:

1. The discourse of urban supremacy over rural ('Urban is better than rural')

2. The discourse of alienable forfeiture ('Becoming rural is a loss')

3. The discourse of historical injustice ('Becoming rural is unjust')

4. The discourse of inadvertent self-victimization (the Sarajevo rose epiphenomenon)

The second step of the research process (explored in detail in this paper) involved unpacking these four discourses in order to provide a fuller picture of the phenomenon and, in extension, an understanding of the rationale underlying current rural-urban conceptualizations in Poland. This, however, may prove difficult due to lack of clear method in many conceptual papers. Mindful of this, this paper follows the protocols for conceptual research as outlined by Xin et al. (2013) and Tribe and Liburd (2016), which signify "a process of scoping, comparison, reflection and abstraction (...), including defining concepts, comparing them, historical analysis, the construction of conceptual typologies, finding conceptual gaps, deep reflection, synthesising and finally a reconceptualisation of the subject" (Tribe \& Liburd 2016, 45). More specifically, this is done by combining historical deconstruction (cf. Munslow 2006) with situational analyses (contemporary examples) and rhetorical techniques (analogies, metaphors, similes), assembled to articulate the (il)logic embedded in the identified discourses.

In line with the stipulation that conceptual research should also seek to "avoid any methodological strait-jacketing and remain open and creative in [its] thinking" (Tribe \& Liburd 2016, 45), the here employed analytical framework is deliberately eclectically informed. The reason for this is that cultural concepts are never theoretically hermetic but build on multiple aspects of the noösphere (the sphere of human thought), and since many of these aspects show common features they can be taken to represent a boundary-spanning conceptual nucleus (Hansen 2011). Likewise, rural-urban conceptualizations as used and implemented by Polish researchers, policy-makers and "lay people" alike form a consequential blend of philosophical, psychological, epistemological, sociological, political, and historical contingencies (cf. Dymitrow et al. 2017), whereby a meta-theoretical, synthetical method of approaching them allows for a fuller elaboration of the Polish notion of 'rural' and 'urban'. Adopting such an analytical scheme, the data underlying the presented arguments and counterarguments on the nature of degradation were acquired from archival documents, including original legislation, and from the most reliable historical studies. Contrarily, insights on the tangibles of restitution (current state, predispositions, effects, etc.) were obtained from statistical materials (mainly the Central Statistical Office of Poland) and contemporary scholarly analyses.

In terms of structure, the discussion is held in four discursive openings, each of which deals with a specific aspect of rural-urban ideation that has not received sufficient attention. A brief introduction to Poland and its 'rural-urban problem' precedes these openings, while a conclusion finalizes the paper.

\section{Poland and the rural-urban problem}

As implied earlier, the rural-urban distinction is "a messy and slippery idea that eludes easy definition and demarcation" (Woods 2010a, 1). One of its less known faces is the phenomenon of degraded and restituted towns. This lack of reconnaissance, however, is perhaps less the result of the towns' scarcity than their specificity of being 'awarded' or 'deprived of' an urban label by means of strictly sociopolitical actions. 
In Poland, all settlements are classified as either "urban" or "rural". The default state of any one settlement is "rural" while obtaining urban status is granted by legal means, i.e. by the Polish government, upon prior application from the local municipalities. There are a number of criteria a formally rural settlement must fulfil in order to meet with a positive governmental decision. These criteria converge in four dimensions: 1) spatial-infrastructural; 2) demographic; 3) social; and 4) historical-administrative (Kudra 2014; Szmytkie 2015, 300-301). While the first three raise little doubt in view of commonplace understandings of urbanity (sufficient population, relatively large catchment area, modern infrastructure, various social institutions, a pronounced non-agricultural employment sector etc.), the fourth dimension (possession of urban status in the past) forms a vent, through which the cultural dimension is allowed to enter formality. The main problem lies in the fact that the first three sets of criteria are often met with several, often significant, concessions once the historical criterion is fulfilled (Dymitrow 2015, 95; cf. also Kudra 2014). This in turn forms a loophole for the many "degraded towns" in Poland to reclaim urban status by recourses to history - a process known as "restitution".

So what exactly is a degraded town? A degraded town, shortly, is a small, formally rural, settlement that has had urban status in the past, but today may range from being "fully urban" (i.e. fulfilling all stated criteria) to "fully rural" (fulfilling none of the criteria save for the historical). A restituted town, contrarily, is one whose interim rural status has been revoked, making it formally urban again. Degraded and restituted towns, hence, are geographical units made 'rural' or 'urban' instantaneously, irrespective of their de facto state along what is widely considered a gradual path of (de)urbanization. In Poland there are currently 832 degraded towns and the number of restituted towns increases every year as the benefits associated with the discourse of restitution proliferate. Between the years 1977 and 2017, 122 new towns were 'created', of which 76\% were restitutions (Krzysztofik \& Dymitrow 2015b). But there is a catch. While degradation and restitution are spontaneous, cultural phenomena that both erupt and self-immolate from circumstances much detached from some "objective" definition of urbanity/rurality respectively, the way they are framed by various institutional processes signals the existence of an objectified yet divisive rural-urban reality. Two caveats come to mind.

Firstly, the addition of the historical-administrative dimension means that the Polish definition of 'urban' is based on the historical concept of 'town privileges' that has gradually segued into a contemporary formal definition of 'urban area'. This insistence is retained despite rural-urban classification of Polish settlements being known to have a long history of chaos and inconsistency, brought on by 123 years (1795-1918) of its territory belonging to three, much different, administrative systems: Russian, Prussian and Austrian (Grossman 1925; Szturm de Sztrem 1925; Mazurkiewicz 1967; Kołodziejczyk [1961] 1979; Spórna et al. 2015a). Moreover, the official definition of a 'rural' unit in Poland is "a compact or dispersed settlement with existing agricultural functions or agriculturerelated service and tourism functions, which lacks town privileges or urban status" (Sejm of the Republic of Poland 2003, 2; emphasis added). Effectively, the conceptual core for designating urban and rural areas in Poland has remained largely unaltered for the last 100 years, while setting into motion the bureaucratic vehicle of changing a label from 'rural' to 'urban' departs from a functional rationale (cf. Sokołowski 2015; Krzysztofik et al. 2017a) - an ontological claim that has faced the opprobrium of contemporary scholarship (cf. Halfacree 2009b). By mixing historical factors (traditionalism) with contemporary conditions (rural-urban blurring), in Poland there are "cities" of less than 900 inhabitants and "villages" of 12,000 . Still, this way of rural-urban thinking continues to underlay Poland's administrative structure, and inadvertently inform its policies, spatial planning, wage level differences and eligibility for label-specific governmental state subsidies (Koter 1999, 26; Plucińska 2009)2.

Secondly, in spite of the latter, Poland's development is starkly associated with a rural-urban perspective, including its allocation of funds (Gorlach \& Foryś 2003, 289). Programs supporting innovation and large investments, for instance, are conceptually designed to further a growth-oriented brand of development widely understood as 'urban'. Conversely, so-called 'rural' programs revolve around the restructuring of the primary sector, and only to a lesser extent support more general activation schemes (cf. Szymańska 2013). Even with the more 'open-ended' programs (such as those subsidized by the EU), national distribution of resources is likely to be channeled through domestically 
engrained spatial (here: rural-urban) conceptualizations (Halamska 2013; Dymitrow et al. 2017; Krzysztofik et al. 2017b).

Effectively, when rural-urban labeling is done in a relentlessly dichotomous fashion while relying on a medieval concept in reference to contemporaneity, it is likely to artificially uphold socio-economic and cultural segmentation:

There is reason to believe that instead of reducing spatial differences, unreflected approaches to "rural" and "urban" planning may perpetuate a "default" rural-urban divide by ascribing certain (labelled) spatialities special qualities and attuning those to specific areas of priority (Krzysztofik et al. 2016, 319).

A new generation emerges, one that is neither urban nor rural - just a working one (Strzemińska 2011; my translation).

We are entering the territory of chaos with appearances of certain stability; referring to myths will not help solve problems (Halamska 2014; my translation).

Indeed, the 'rural-urban problem' in Poland has been enunciated as "at least as important as the eastwest development dichotomy" (Ministry of Labour and Social Policy 2006, 17), and pointed out as "the main factor destabilizing Poland's development and the functioning of democratic institutions in the longer term" (Gorlach \& Foryś 2003, 296; cf. also Bukraba-Rylska 2011; Śpiewak 2012; Halamska 2013). However, although the negative effects of rural-urban labeling are beginning to be noticed, the way this rural-urban fissure is construed in the first place is rarely addressed, and almost never critically (but see Kubicki 2011; Wójcik 2013). Because the distinction between formal urbanity and cultural urbanity is neither sufficiently differentiated nor problematized (Dymitrow 2014), confusion arises with regard to the purpose of 'rural/urban' in Poland, making societal actions that depart from such a distinction contentious and difficult to successfully operationalize (Feltynowski et al. 2015; Biegańska et al. 2016; Dymitrow et al. 2017).

To conclude, while the definition of rurality/urbanity in Poland is relatively "simple", its conceptualization is much more multilayered. As this complexity is seldom accounted for, a ubiquitous cultural idea becomes reduced to an underconceptualized theme in view of the most recent vicissitudes surrounding the scholarly rural-urban debate. Such discursive one-sidedness can then lead to what Koch $(2005,5)$ described as the missing symmetry of constructionism in the relationship of space and society, whereupon the spatial effects of the social construction (here of 'rural/urban') may pass unnoticed and eventually induce various pernicious outcomes, including compromised communication, misdirected resources and cultural segmentation. Given the immense imbrications of qualities found across the rural-urban range in Poland, "Polish urbanity" today, for all intents and purposes, could equally well act as a 'default state', with 'rural' being the status to be applied for. Although why this cannot be the case will be elaborated in greater detail in the next section, the sheer construction of a formalized rural-to-urban (and vice versa) transition in a $21^{\text {st }}$ century reality calls for a discursive deconstruction.

\section{First discourse: Urban is better than rural}

The first, and most visible discourse I would like to discuss is that of a perceived urban supremacy over rural. Having in mind that elimination of unnecessary bureaucracy is key to modern managerial theory (Wren \& Bedeian 2009), the sea of officialdom surrounding the process of changing an area's label from 'rural' to 'urban' in Poland is perplexing. Despite this bureaucracy and - what more - the uncertainty and unpredictability of outcome in the process of restitution (Sokołowski 2002; Drobek 2004; Dymitrow 2012), the non-declining number of incoming petitions points to the desirability of the concept of urbanity in Poland. 'Urban' continues to remain an exclusive achievement endorsed by complex procedures and sets of specific criteria. Disregarding the fact that the difference between urban Warsaw (1,8 million) and "urban" Wyśmierzyce of 900 inhabitants is mindboggling, the very fact that everything else is lumped together into one category - 'rural' (arable fields, forests, meadows, national parks, mountain ranges, marshes and, indeed, human settlements of up to 12,000 inhabitants) - makes urbanity stand out as something of an indulgence. 
Sadly, this is often done amidst crass myth-making and insidious rhetoric. Consider the following litany of elusive "benefits" from urban status as enumerated in a leaflet prepared by the local authorities of the degraded town of Lanckorona, and distributed to its residents in the lead-up to a local referendum on the town's possible restitution.

Greater access to specialist health services (doctors, rehabilitation); local branches of departments in the municipal office, such as communication (driver's license, registration documents) and construction (permits); greater choice and assortment of cultural events; possibility to study at a secondary school or a local university branch; transport facilities (greater number of buses and minibuses with more frequent plying); eligibility for EU-grants reserved for small towns; ensuring safety in the town by installing a police station [...] (Łopata 2016; my translation).

Unfortunately, little of this is true, as urban status is neither required nor guarantees the envisioned development (cf. Krzysztofik \& Dymitrow 2015a). The fact that a provincial town of 2000 would attract a university branch, or any other branch for that matter, just because it changed its label from 'rural' to 'urban' is an extreme hyperbole; neither are there EU-grants reserved for "small towns". Since installment of most of the presented facilities lies at the discretion of the municipal council, relying on "urban status" to do the job only reveals the council's level of resourcefulness.

Of note is that this kind of rhetoric is omnipresent in the discourse of many local authorities and of the lay residents endorsing it; what is more, it is also reiterated in many academic studies on the phenomenon of restitution (cf. Dawidejt-Drobek \& Drobek 2015; Konecka-Szydłowska 2015; Zaniewska et al. 2015). However, since the immediate socio-economic gains of urban status are unclear and confusing, the reasons behind the often fervent and persistent struggles for urbanity must be sought elsewhere. Acknowledging that "our ways of talking do not neutrally reflect our world (...) but, rather, play an active role in creating, and changing [it]" (Winther Jørgensen \& Phillips $2002,1)$, the sheer designation 'degraded' assumes the existence of asymmetric power relations. The prepositive 'degraded' implies some kind of breaking or wearing, damage or failure, loss of quality, maybe even decomposition or disintegration. Degradation may thus either be abstract or concrete, and both can apply to settlement forms. Most often, though, the expression 'degraded town' refers to a locality bereft of the conceptual casing ("town") of its putatively essential mode of existence ("urbanity") in an "unnatural" way (i.e. related to an act, not a process). Degradation, hence, seen as a decrease in rank rather than in content, refers to what I would call conceptual degradation. Studies on the specifics of towns deprived of their urban status use the term 'degraded town' in this way (e.g. Adamczewka-Wejchert \& Wejchert 1986; Drobek 1999; Murzyn \& Gwosdz 2003; Miszewska 2007; Borcz et al. 2009; Sokołowski 2011; Krzysztofik et al. 2015; Szmytkie et al. 2015). In other words, the ghost of Beaujeu-Garnier and Chabot's $(1963,115)$ aphorism on a town being nothing but a village that has been successful seems to live on. Contrarily, no former town has ever been referred to as 'upgraded' to rural status in a Polish context. In a reality where thinking in rural-urban categories seems incontrovertible, identifying hegemonies is crucial to avert unreflective understandings of these popular concepts from ricocheting into eponymous development strategies. In that vein, attributing a classifier imbued with negative connotations (like 'degraded') to a certain concept ('town') is indicative of the Polish attitudes towards 'rurality' and how that knowledge has become consolidated in the first place.

Understanding this "lock-in" requires a historical detour. Beginning in the $13^{\text {th }}$ century, Poland's settlement system has evolved over a long time. The purpose of the earliest cities was to provide for trade, administration and defense, while the countryside supplied food and fiber for the cities. With the onset of industrialization in the late $19^{\text {th }}$ century, small towns devoid of industry slowly declined, what effectively fortified the rural-urban divide (Gawryszewski 2005). The two World Wars (especially the second) shattered the Polish settlement system, while the ensuant imposition of Communism saw two tasks: to rebuild the country and to collectivize production. Both laid the basis for momentous alterations to the gradual evolution of Poland's topography, hitherto faithful to a rural-urban matrix. Focus on heavy industry led to innumerable constructions of huge high-rise block estates for both urban and rural populations. The rural-urban erasure was also visible in the many new monofunctional industrial settlements and military plants that sprung up in the middle of nowhere (Krzysztofik 2014). Another groundbreaking trademark of this era was the State Agricultural Farm (PGR). Built in the effigy 
of small cities with modern infrastructure galore, the PGRs eradicated all traditional rural-urban difference there was (Biegańska et al. 2016; Dymitrow et al. 2017).

The events of 1989 saw a systemic transformation in the former Eastern bloc that affected the whole society (Lee 2002). Effectively, new values surfaced along aspirations to erase old ones (Dębski et al. 2010). Resentment towards the tired Soviet-style urbanity based on heavy industry and the hubristic belief of being able to manage all aspects of human life gave rise to a return to "Polish values" and a reconceptualization of an 'urban ideal' based on recourses to the past (Dymitrow 2014). This brought about the re-emergence of the city as the nexus of civilizatory progress while downplaying the value of rural areas. Reinterpretations of the city as "an outpost in a sea of rurality" (Gold 2009, 150), starkly reinforced the discourse of prosperous modernity (cf. Berman 1983) despite the fact that 'rural areas' have begun to be envisioned through new conceptual developments in their own right (cf. Munkejord 2011; Corbett 2014; Rytkönen 2014). This was particularly interesting in view of the fact that agriculture, the defining characteristic of Polish rurality, which in the recent decades had to yield to drastic economic changes. Although agriculture - as of 2016 - only employs $10.6 \%$ of Poland's working population (compared to 22\% in mid-90s) (Rynek Pracy 2016), the definition of a 'rural' settlement in Poland still involves the existence of agricultural or agriculture-related functions (Sejm of the Republic of Poland 2003, 2).

The fact that Poland only has 923 urban units and more than 43,000 rural ones is a revealing ratio. As Poland has not formally revised the conceptualization underlying its rural-urban structure (despite numerous administrative reforms) "rural-urban" eventually came to lack a workable contemporary matrix, and is instead reaching back in history for a definition. This 'reaching back' has also changed the governmental discourse when evaluating what is to be considered 'urban' (Szmytkie 2015), alongside many other changes brought on by the ideological shifts: "if something existed before the war but was revoked during Communism, it needed to be brought back" (Mikołajek 2012; cf. also Pavković et al. 1995). By the 1990s, hence, the concept of 'cultural heritage' began to be sanctioned as a valid argument for granting urban status to minuscule 'degraded towns', and continues to this very day (Dymitrow 2013). This created a peculiar situation: contemporary outlooks on 'urbanity' became conflated with an expired definition of it, while development-oriented aspects of urbanization became irredeemably entwined with emotional issues.

In his comprehensive situational analysis of contemporary Poland, Zaremba (2016) argues that while "the economic gap between the city and the country has narrowed significantly (the same mental journey into modernity that took Sweden 70 years, Poles completed in 20), the mental gap has become wider." Contemporary language reflects this grim reality, oozing with class contempt: "If you want to humiliate a Pole", Zaremba continues, "you call him a peasant (...) - just as the gentry spoke of their serfs" (cf. also Bukraba-Rylska 2011). Zaremba's main concern, however, is that the mental ruralurban gap in Poland has come to poison the politics, attributing - among others - Poland's vote for a "reactionary government" in 2015 to "the cultural war between the city and the country-side." This trend, as Bukraba-Rylska (2011) notes, was created and is maintained by opinion-making elites, which claim that the countryside constitutes developmental ballast for Poland, the relinquishment of which is the only way of obtaining current standards of "modernity".

However, as numerous historical accounts show, the rural-urban binary has never been portrayed as a neutral conceptual pair but as a battle of discourses, with one ousting the other at some point in history (Williams 1975; Woods 2010a). The concepts of degradation and restitution are problematic in this respect in that their deployment cherry-picks stop-images of rural-urban relations from one period and sustains them in a reality of much changed values and perspectives. When historicization of past national memories is not interpreted from the circumstances of their time but is chosen to fit into the contemporary ruling master narrative, it is referred to as a Whig history outlook (cf. Davies 2011) - an insidious instrument of political manipulation. It is all too often forsaken that the mere usage of a(ny) concept on a systematic basis (rural and urban included) curtails maneuverability to address the complexity of social problems by discursively steering intervention into prepackaged avenues, often with dire consequences (cf. Cloke \& Milbourne 1992; Woodward 1996; Brauer \& Dymitrow 2014, 2017). The seemingly innocent concepts of degradation and restitution are tacit reaffirmations of this intricacy. 


\section{Second discourse: Becoming rural is a loss}

The second discourse I would like to discuss is that of alienable forfeiture, or transferrable sense of loss. Due to the unobtainability of urban status by many degraded towns in light of the bureaucracy surrounding it, the discourse of loss becomes especially expressive. The justification is simple: a degraded town 'should' be urban again simply because it was urban in the past (Drobek 1999; Siemiński 2000). Such rhetoric is present directly in many utterances of local politicians and cultural associations who weave it into the discourse of heritage (cf. Dymitrow 2013). Also, on an academic level, many studies devoted to the issue of degraded towns tend to evaluate them on account of their eligibility for urban status using an armada of more or less sophisticated indices (cf. Sokołowski 2015; Szmytkie 2015). This is also a premonition - although more indirectly so - of viewing degraded towns in the light of their potential of restitution, which, in turn, is symptomatic of a subtle stress on their 'wrong state'. The point is that the emotive states of mind underpinning degradation and restitution often tend to alienate the concepts of 'rural/urban' from their semantic core towards other aspects, which are clearly secondary to the debate. The discourse of loss is tricky in this respect, and while spotting it is relatively easy, understanding the logical fallacy it entails is philosophically more demanding. Because of that, the discourse of loss is probably best illustrated through the use of metaphors and analogies, rather than real-life examples.

First of all, the notion of restitution (prefixed re-) implies that something is being recovered or reinstated. In the case of settlements ending an era of certain conceptual designation ('urban') (because what lay at the core of that concept has been deemed to no longer correspond with the content subject to urban labeling), however, is not necessarily the same as losing something. Such thinking tends to be emotionally laden. A typical example of this is the process of aging, which often is synonymous with 'losing youth', 'losing virility' or 'losing beauty'. Although we do know that aging is a natural, multidimensional process of accumulated changes of physical, psychological and social nature, we tend to romanticize the superiority of young age (freshness, vigor, spirit) over old age (disease, loneliness, pauperization). In such a perspective the imbalance between positive and negative aspects becomes perturbed, with the imperfections of 'lost youth' (insecurity, naïveté, dependence) and advantages of 'gained maturity' (wisdom, experience, reflexivity) becoming subdued, if not overlooked. Similar intimations can be found in a number of transitional human conditions, such as death ("loss" of life), alopecia ("loss" of hair) or defloration ("loss" of virginity), where loss is understood as the absence of something of value (compare to the corresponding "restitutive" practices of resuscitation, hair transplantation or hymenorrhaphy). Conversely, it is not seen as 'getting rid of something' (like a tumor, nail/hair clippings or a tattoo) or, perhaps most importantly, it is discursively less framed as a 'natural' transition from one phase/state to another.

Secondly, the discourse of restitution often involves semantic discontinuities. It is difficult to speak of restitution when what is considered "lost" is something very different in its "restituted" rendition. When a couple grieving the death of a child decides to have another one, it does not imply "restitution" of a family member; although the psychology behind their motives may be explained in those terms. Hence, filling an apparent gap with totally different content matter may be perceived as an act of restitution, but in fact only manifests an act of desperation, to quite different effect. Consider if only the fact that the concept of urban status in Poland today is still referred to as 'urban (town) privileges' (prawa miejskie). Dating back to the Middle Ages, town privileges, whose original meaning (right to trading, establishment of guilds, etc.) is long gone, have no longer practical importance per se; it is merely a cultural remnant reified in the format of a labeled administrative demarcation. The only common denominator is the sheer term 'urban' (miejskie), while its discursive fixture at an unspecified point in history (cf. Woods 2010a, 43-44) is never accounted for.

In all fairness, at this point it is important to stress that the level of 'urbanity' of any one degraded town today may (and, indeed, sometimes does) correlate with its historical 'urbanity', but only - and only - if we as a common denominator feel confident accepting the town's fulfilment of time-specific (past and current) criteria for urbanity. At the same time, many times there is no such correlation (cf. Kantor-Pietraga 2014). This relation has been captured by Halfacree (2009b) in his ideas on how the concept of rurality, and - by contrast - of urbanity, can be positioned today. Drawing on Jean 
Baudrillard's ideas of the age of simulations "where the map no longer follows on from the territory, seeking to represent it, but in-stead 'precedes' and 'engenders' it" (ibid., 392), Halfacree points to the current tendency to corral assemblages of rurality that go 'beyond' the rural. This can happen when a particular quality of life becomes heavily infused with particular representations of rurality so that the existing rurality is reconstituted to resemble more closely what rurality is 'supposed' to look like, or even outdo what most people would acknowledge as rural space (see also Brauer \& Dymitrow 2014). In regard to degraded towns, when a town's constitution of aspects chosen to represent a state commonly understood as 'contemporary urbanity' differs excessively from the state the town represented in the past, or, worse, if the current state exceeds its urban historicity, then the argument of loss is merely a contextually random cultural reference.

Since the discourse of loss is heralded semi-officially by the government (past possession of urban status is considered a merit in the process of granting urban status, cf. Szmytkie 2015), several aspiring yet insufficiently 'urban' degraded towns have used this argument in their fights for restitution (e.g. Gardeja, Lubycza Królewska, Skierbieszów, Parzęczew, Dobre, etc.), to no avail. In effect, the cultural vs. formal understanding of urbanity is a confusing concoction of perspectives enmeshed in the deontology of degradation when expressed through facile efforts to bring order, objectivity and formality into the culturally burdened rural-urban theme. In any one case, wanting to become urban by pretending to be urban by invoking urban schemata from the past to obtain current benefits of urban status (which are neither clear nor guarantee the expected way of development) entails a problematic perspective, where 'modernity' comes across as a false prophecy (cf. Murphy 2010). This is particularly visible in the discourse of restitution, the real effects of which are often questionable (Konecka-Szydłowska 2015; Przesmycka 2015).

\section{Third discourse: Becoming rural is unjust}

Derivative of - yet morally different from - the discourse of loss are qualities relating to the unfairness of degradation and the associated discourse of historical injustice. Oftentimes these qualities are assembled and expressed through the practice of restitution, which, if used as a medium to channelize feelings of betrayal, become a discourse in themselves. This discourse is particularly visible in cases of degradations enforced by a foreign oppressor or by native Communist authorities. It often involves claims that degraded towns should be exempt from the restitution process because degradations (allegedly) enacted by undemocratic means are an act of violation, for example in statements invoking "reversal of historic justice by a free Poland" or claiming that "law is law but history is history" (Grzegorczyk 2009). Since, currently, many restitutory movements are accompanied by a desire to correct a situation that had taken place in the past (cf. Dymitrow 2013), it is important to understand the specifics that preluded and accompanied the very act of degradation. This, in turn, calls for a historical deconstruction based on archival documents, which often tend to get "lost" in the process.

While this is not the place for a comprehensive review of Poland's history, a minimum of political background (after Gawryszewski 2005) is required to grasp the context. Until the $17^{\text {th }}$ century Poland was a great power and territorially one of Europe's largest countries, stretching from the Baltics to the Black Sea. During the 1700 s, the country's stability was severely shaken under a weak monarch. This ultimately led to Poland's division (in 1772, 1793 and 1795) between its neighbors Russia, Prussia and Austria, and subsequent annihilation. Poland resurrected after World War 1 as the short-lived Second Polish Republic (1918-1939), only to become occupied 1939-1945 by Nazi Germany and made a Soviet satellite state 1945-1989. Because the time of Polish annihilation (1772-1918) saw the greatest number of towns made formally rural (483), the concept of degradation is typically discursively attributed to this period.

One notable example of this is the infamous administrative reform of 1869-1870 that revoked the urban status of 336 Polish towns (Journal of Law 1869). Enforced in a radical manner by Imperial Russia concurrently with the events of the heroic Polish-led January Uprising of 1863-1864 (which eventually ended Poland's limited autonomy through its full incorporation into Russia), the reform is emotionally charged amongst Poles. As such, it is often interpreted as a form of repression for participation in the Uprising, both in scientific accounts (cf. Koszutski 1915, 5; Gajewski 1964, 87; 
Siemiński 2000, 16; Miszewska 2007, 36; Mielcarek 2008, 56; Dawidejt-Drobek \& Drobek 2015, 50-51 etc.) and whenever the question of 'restitution' becomes topical (cf. Dymitrow 2013). In the context of the latter, the exploitation of repression-induced acts of degradation is so widespread that that the discourse of injustice is even being transposed onto reversals of urban status that had absolutely nothing to do with it. For instance, the restituted in 2016 town of Siedliszcze had its urban status revoked on 10 April 1821 (Kommisyja dla Miast 1825; Rodecki 1830). However, in its pre-restitutional campaign it was widely heralded that the degradation happened "after the January Uprising of 18631864" (e.g. TVP Lublin 2015) or - chronologically more correctly, although still vastly exaggeratedly "slightly before" (by 42 years!) the Uprising (e.g. Barczyński 2015). In any one case, the very mentions of this Uprising - rather than to simply state the exact date of degradation - bring to mind images of crushed Polish resistance and works as a way of reproducing the Russian repression narrative ${ }^{3}$. By so doing, degradations are implicitly portrayed as unjust (be it by historical ignorance or by deliberately forging history), which in turn helps prop up restitution, and especially so in questionable cases (such as Siedliszcze, the least "urban" of the newly restituted 98 towns (cf. Spórna et al. 2015b, 416).

Notwithstanding factual mistakes, the sheer epitomization of the vast scope of this reform as a uniform Machiavellian action overshadows a host of intricate, individualized circumstances that may have been incumbent at the time of the reform's execution. Despite the diffusion of the punishment theory, the arguments used to justify it are inconclusive. If we consider the criteria underlying the reform, none of them strikes as unreasonable in view of the reform's own assumptions (Journal of Law 1869): a town predestined to degradation must have had less than 3000 inhabitants, its farmers must have accounted for at least $50 \%$ of the population, and the town's yearly revenue must have been smaller than 1500 rubles. These three criteria, demographic, functional and economic, even today are considered some of the most frequently reiterated denominators of the concept of urbanity (cf. Pacione 2009). Focusing if only on the most easily verifiable criterion, the demographic one, shows that the demographic requirements of the reform were met by $93.1 \%$ of all towns (Journal of Law 1870), meaning that almost all degraded towns were in fact very small.

In her detailed study of this reform, Nietyksza $(1986,10-11)$ contends that by the mid-19th century reinvigoration of the Polish concept of urbanity was necessary as many small towns had long lost their urban functions while still retaining urban status. As Nietyksza $(1986,93)$ notes, the actual importance of urban status of many towns subject to 'degradation' had been reduced long before the reform. The abolishment of patrimonial relations in private cities and the removal of the towns' monopoly on trade were some of the measures undertaken immediately prior to the reform to diminish the impact of the rural-urban distinction in practice. Moreover, the correlation between punishment and revocation of urban status is not well crystallized as most 'reform towns' had not been involved in the Polish antiRussian uprisings, while many towns that had been involved in them escaped degradation despite not even meeting the postulated criteria (Zieliński 1913). There were even instances of voluntary requests for degradation to (pragmatically) avoid the higher costs of urban administration. Today, thus, campaigning for a "return to urbanity" by invoking historical events is not uncontroversial. Statements depicting degraded towns as "a testimony offoreign violence, old injustice and present incomprehension" (Siemiński 2000,14) may very well be true in ideological terms, but not necessarily in view of some more objective (countable) indicators. In effect, seeing the reform as an act of repression is a largely reconstructed oversimplification (cf. Sokołowski 2011; Dymitrow 2013), and, as such, may unwittingly pave the way for a reactionary, rather than proactive, way of restitution (cf. Bendix 2000).

To strengthen this point, let us compare the reform of 1869-1870 to degradations deployed in other parts of Poland (i.e. beyond the Russian-occupied territory) and in different temporal contexts. In the Galician section of Poland (seized by the Austrians following Poland's partitions), a major reform was conducted in 1784-1785 with the intent to classify all settlements as either towns (Städte), market towns (Marktflecken) or as villages (Dörfer), with the first two considered 'urban'. However, in his indepth study on the subject, Karpiniec (1932) found that the reform was introduced only as a means to compile the index for the official map of Galicia, and had little in common with the settlements' actual character. Moreover, the classification varied widely between different sources. As a result, the exact number of urban settlements was never known, and, more alarmingly, a reform conducted for fairly trivial reasons posed serious problems when Galicia returned to Poland in 1918 and when its chaotic 
urban-rural structure came to assume formal meaning. This created formally urban units without town privileges and rural municipalities with urban status. Moreover, both rural and urban communes could comprise settlements with Marktflecken status, complicating the situation even more. A necessary reform set out to correct this historical cocktail was executed in the years 1933-1934. It at the same time standardized the equally chaotic situation in other parts of Poland. Effectively, as a result of the reform of 1933-1934, up to 722 towns were deprived of their urban denominator (Dymitrow 2015, 104). However, since the reform was conducted by Polish authorities, the issue of historical retribution - so often invoked in the discourse of contemporary restitution campaigns when pertaining to degradations enforced by Imperial Russia - is disconcertingly silenced, even though the factual circumstances surrounding both reforms may have been very similar (e.g. the towns being too small or too poor).

Now let us consider the causes. In much of Central and Eastern Europe, russophobia has historically represented the greatest national fear and the most influential one (Taras 2010). Although outworn stereotypes of different nations abound in popular consciousness, Russia, due to its longevity, has attracted more than a fair share of these. In the perception of Poles Russia is notoriously associated with events such as conquest, occupation, annexation, enforced Communism, the Iron Wall, mass deportations to Siberia and Gulag labor camps (Otok 2009). Even currently the Polish-Russian issue is overwrought as a result of the intensity and ways in which various political events involving Russia are being portrayed in the media. Poland's willingness to house a US missile defense complex aimed at Russia was one such example. Another was the unfortunate 2010 crash of the Polish governmental plane at Smolensk, which took place prior to a scheduled commemoration of the Soviet-executed Katyn massacre. The most recent (2014-2017) events in the Ukraine - Russia's annexation of Crimea, the war in Donbass, or even seemingly trivial episodes such as Russia's withdrawal/expulsion from the 2017 Eurovision Song Contest in Kiev - are yet another affirmation of context-specific events which are let to envenom the strained Polish-Russian relations in a much broader sense. The medial image of "Russia's ruthless pursuit of expansionist and imperialist agendas" (Taras 2010) is so commonplace that it creates a discursive field whose load is likely to discharge - often subconsciously - to other, thematically more or less unrelated, contexts. In instances where this discursive linkage is not directly apparent (or obscured by years of propagandist monovocality) certain statements, or "facts", are less likely to be questioned and reflected upon. This, in turn, creates a silent ground for their justification. In regard to the reform of 1869-1870, there are plenty of indications that the overarching discourse of anti-Russian sentiment tends to overshadow the true circumstances surrounding it, mainly due to lack of criticism when confronting poorly researched yet ubiquitous information about the nature of this event.

If we deconstruct the concept of urbanity to its constitutive parts, this becomes more apparent. A town that has seen a decrease in, say, 500 inhabitants, cannot be blamed on 'injustice'. It is an objective, countable diminution conditioned by various environmental events (Krzysztofik et al. 2015). The same can be said about changes observed in a town's morphological or functional structure. In other words, observable changes do not trigger spurious reactions of emotional character, but changes transposed onto the conceptual arena do. As such, there is a tendency to imbue the concept of degradation with a sense of imposed injustice because it solidifies an objective reality through a conceptual reshuffle. For this very reason, degradations in Poland are no longer deployed, while the established criteria for granting urban status are increasingly geared towards concessions and modifications made to facilitate aspiring degraded towns in fulfilling their restitution (Dymitrow \& Krzysztofik 2015).

In summary, all these tendencies suggest that the premises surrounding the time of degradation are often not well understood, as is their connection to the towns' current situation. As Bendix (2000, 38) put it,

[w] hat distinguishes heritage is its capacity to hide the complexities of history and politics [and its role as] a beautifying gloss, rendering the specificity of past political, economic, and social experiences into far less complex whole than what socio-historical scrutiny would reveal.

We need to be wary of the difference between 'fact' and 'interpretation', and especially so when 'fact' is of historical nature (and unreachable due to poor or unobtainable documentation) and pertains to values of high social interest, such as money, pride, nationalism, and the like. 


\section{Fourth discourse: The Sarajevo rose epiphenomenon}

Last but not least, I will briefly touch upon a basic idea that undermines the concept of degradation (and - in extension - restitution): the discourse of inadvertent self-victimization. Because urban status in Poland today is (discursively) widely associated with greater chances of development, it is unclear whether the sudden interest in historical events is used as a method to bypass the law (cf. Graham et al. 2000), or whether it is the law that stands in the way of fulfilment of a process based on cultural, non-economic identity (Sidorenko 2008)4. In any one case, the notion of degradation unmistakably feeds on a deleterious recourse to the past, whose enmeshment in current administrative constraints may incur undesired developmental effects.

This characteristic epitomizes a condition, which I would like to describe as the Sarajevo rose epiphenomenon. Sarajevo roses are a type of cultural remnant found throughout the Bosnian capital of Sarajevo, a site of intense urban warfare during the Bosnian War of 1992-1995. Mortar rounds (more than 300 a day) landing on the concrete created unique fragmentation patterns very similar to roses. These floral scars, instigated by the explosion of mortar shells, were later filled with red resin in the effigy of the blood of those killed in the incident (Campbell 1999; Schwartz 2005; Frawley 2014). Today, the roses remain scattered throughout Sarajevo as an omnipresent reminder of victimhood (Fig. 1). Although commendable as an homage to the perished ('the phenomenon'), their presence, however, entrains a less desirable epiphenomenon: their power to act as frozen film frames and foreboding depressants whose ghost not only hinders the living from finding alternative life solutions but also keeps the seething Muslim-Serbian conflict ajar. Indeed, since 1995, Bosnia-Herzegovina experiences some of the lowest fertility rates in the world, one of the lowest GDPs per capita in Europe, drastic emigration, high population aging and many other ongoing problems in the aftermath of the civil war (CIA 2015; Pobrić \& Robinson 2015; Riding \& Wake-Walker 2017).

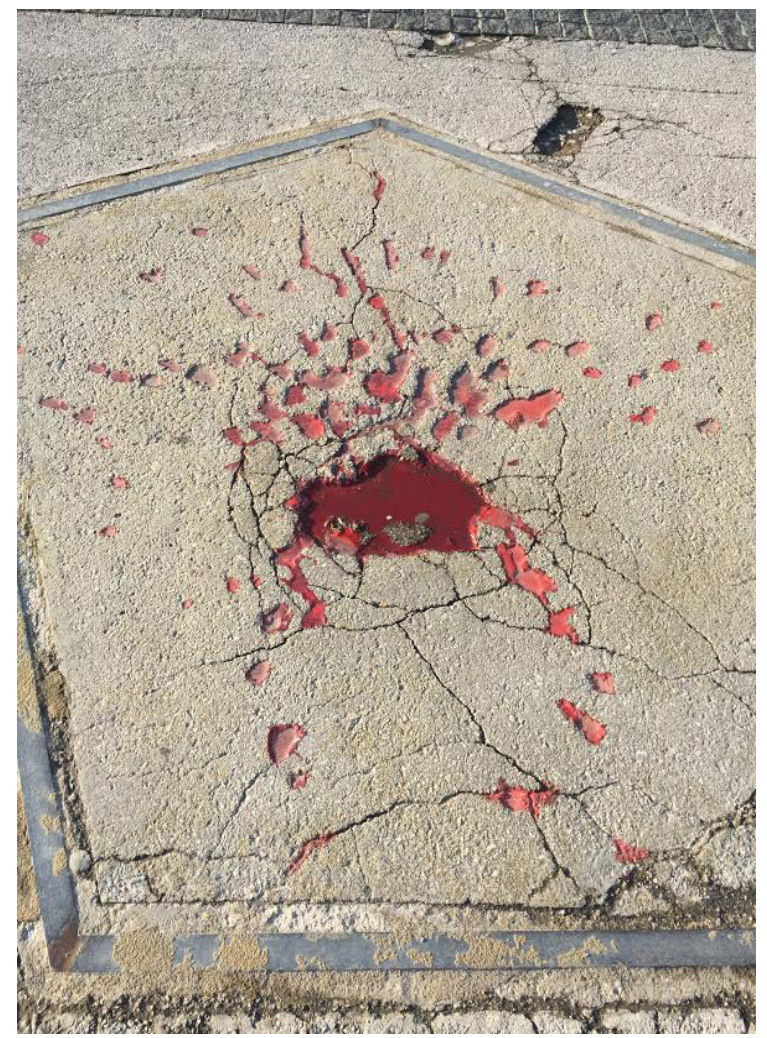

Fig. 1. A "Sarajevo rose" (photo: the author). 
Although quite different in cause and effect, the concept of degraded town shares a number of similarities with the Bosnian case, for which the Sarajevo roses may act as an illustrative simile. The concept of degradation inherently invokes historical scars and keeps the rural-urban conflict ablaze through a specific form of ressentiment (a sense of hostility directed at what one identifies as the cause of one's frustration). While "[m]emory is not trash but useful intellectual and emotional knowledge" (Lubecka 2010,158), one needs to distinguish between memory as an abstract container of contextually inalienable values and memory as a dispositive through which certain discourses gain material presence (cf. Foucault 1977). Although invocations to history may involve an array of different stands (appraisal, nostalgia, pride, fear, resentment etc.), the discursive load added to the concept of degradation entreats stories laden with almost exclusively negative connotations.

One such outcome, sumptuously exploited by local politicians, is the notion (or tactic?5) of selfvictimization, which may play out to quite the contrary effect (cf. Nilsson \& Lundgren 2015). In regard to degraded towns, the celebration of serfdom and suffering amidst the crass commercialism that often accompanies many pre-restitutional campaigns could thus be regarded as a gratuitous use of the concept, in which relentless nourishing on "historical wrongs" may eventually turn morbid and impede fresh future outlooks that depart from current preconditions for sound development:

[Rural mayor of Szczerców:] While our local community could deal with the historical turmoil, the unjust decree [of degradation] is still in force. Don't we owe to future generations (especially those who, for political reasons, have not had the possibility to change this situation) to rectify these historical wrongs? (...) I, for one, cannot reconcile with the idea that the law established by those who deprived us of sovereignty is still valid (Kmita 2014; my translation).

This in turn may unwittingly pave the way for damaging concessions on behalf of the legislative bodies (if urban status is unjustifiably granted as a mere token of commiseration) or - if denied - for unrealistic expectations driven by a form of engineered "urban identity", with demobilizing disappointment as a likely outcome. There is a bottom line to this argument. If a formally rural town is eligible for urban status on account of some objective indicators, and if this status is - realistically - helpful in fulfilling an envisioned line of development, then its current preconditions should suffice to obtain it without resorting to the discourse of victimhood.

\section{Conclusions}

Culture matters. Understanding culture as "the primary source of social progress or regression" (Hirsi Ali 2016), every cultural idea requires definition and conceptualization. While the definition part is relatively easy - it is merely a matter of choice - conceptualization has a different role: it imbues an idea with values, which make it support certain tasks or the doing of things. Conceptual battles, hence, are seldom terminological but are associated with more specific commitments about the philosophy of mind and language (Margolis \& Laurence 1999). Embracing the ontology that 'urbanities' and 'ruralities' today are better understood as social constructs that dictate the human condition rather than as physical environments that necessitate specific actions, this paper has targeted the cultural burden of rural-urban thinking in a formalized Polish context, through a discursive lens. Adopting a conceptual research design, the aim of this paper was to lay bare some hidden discursive filters underlying the concepts of rurality and urbanity through the auxiliary concepts of degradation and restitution, but also to ignite new discussions on the subject.

For one, the Polish practice perpetuates the historical concepts of rural and urban, and the false dichotomy they create, as objective truths and as materialities that exist beyond conversational realities. For another, it perpetuates hegemonic relations by hailing the supremacy and desirability of 'urbanity' over its historically constructed antonym - 'rurality'. It also assumes that degradation is a 'loss' by making comparisons to a (re)imagined historical state, regardless of the (in)accuracy of that comparison across two temporal contexts. Next, given Poland's chequered history due to its location in the 'shatter belt' of Europe, the discourse of degradation imbues past rural-urban relations with historical events, which may or may not have had direct impact on the development of those relations; put simply, by invoking injustice it creates a culprit. Lastly, the incessant invocation to the wounds of the past makes degradation an odd combinatorial legacy of victimhood encased in a contemporary outlook on urbanity. 
Understanding how the phenomena of degradation and restitution saturate thinking in rural-urban categories in Poland is important if we want to isolate particular subject positions and social effects produced through these constructed relationships between people and places (cf. Waitt 2005). Numerous studies have affirmed the disjointedness between formal designations and de facto conditions - on the one hand - and between formal designations and their degree of implementation - on the other. What remains much less explored is that these discrepancies often have little in common with the concepts of urbanity/rurality becoming objectively blurred, but may emerge from specific discourses attached a posteriori to these concepts.

If we acknowledge that the ontological rationale of employing a rural-urban distinction is "to find out whether or not one can identify any aspects (...) that speak of more substan-tial and significant differences between the qualities of the rural and (...) the urban" (Halfacree 2009a, 449), we need to be cautious. This is particularly important whenever the cultural dimension of 'rural/urban' sees formalization under the guise of 'objectified space', as such a conflation of values is likely to extend the faculty of these concepts. Not only can this extension 'contaminate' their intended explanatory merit, but it may also create an artificial problem that runs the risk of loosening and infecting social bonds with no or few identifiable gains. If understanding the world is changing it (Gibson-Graham \& Roelvink 2010, 342), then thinking about change in new ways must involve questioning the assumptions underlying contemporary societal organization. Unpacking the elusiveness involved in the formalization of cultural concepts, and how it is held in place, is a step closer towards that goal.

\section{Notes}

1 The terms 'degradation' (degradacja) and 'restitution' (restytucja) are widely used in the subject literature and have become established and accepted designations for the specific practices of formally changing a settlement's historical label, 'urban' and 'rural' respectively (cf. Krzysztofik \& Dymitrow 2015a). The terms occur in common parlance, academic literature and legislation.

2 For instance, a teacher's job in 'rural areas' decades ago involved lighting a fire in the furnace and shoveling snow outside the school - hence higher salary. Today, this no longer applies but differences in rural/urban salaries remain (Dymitrow et al. 2017).

3 Between the January Uprising (1863-1864) and Poland's regained independence (1918) only two cases of degradations were recorded beyond the scope of the reform of 1869-1870 (Spórna et al. 2015b).

${ }^{4}$ Moreover, some restitutions are known to have been granted beyond substantive reasons by means of political lobbying, like in the case of the town of Lipsk in 1983, the birthplace of a then prominent politician and militia general (Siemiński 2000).

5 The concept of self-victimization has also been identified to involve the fabrication of martyrdom for reasons such as: attention seeking, coping strategy, to manipulate others etc. (Meindl \& Lerner 1983).

\section{Acknowledgments}

I would like to thank Marie Stenseke, Robert Krzysztofik, Therese Brolin and Corey M. Gonzalez, as well as the two anonymous reviewers of Fennia for their valuable contributions to the paper. I also extend my appreciation to the Swedish Society for Anthropology and Geography for financial support.

\section{References}

Adamczewka-Wejchert, H. \& Wejchert, K. (1986) Małe miasta. problemy urbanistyczne stale aktualne. Arkady, Warsaw.

Almstedt, A.., Brouder, P., Karlsson, S. \& Lundmark, L. (2014) Beyond post-productivism: from rural policy discourse to rural diversity. European Countryside 6(4) 297-306. https://doi.org/10.2478/ euco-2014-0016

Anderson, B., Kearnes, M., McFarlane, C. \& Swanton, D. (2012) On assemblages and geography. Dialogues in Human Geography 2(2) 171-189. https://doi.org/10.1177/2043820612449261

Barczyński, A. (2015) Siedliszcze było już miastem dwa razy. Zostanie po raz trzeci? Dziennik Wschodni. $<$ http://www.dziennikwschodni.pl/chelm/n,999994471, siedliszcze-bylo-juz-miastem-dwa-razy-zostanie-po-raz-trzeci. html> 06.08.2015. 
Barnes, T.J. \& Duncan, J.S. (eds) (2013) Writing worlds: discourse, text, and metaphor in the representation of landscape. Routledge, New York.

Bawaka Country, Wright, S., Suchet-Pearson, S., Lloyd, K., Burarrwanga, L., Ganambarr, R., Ganambarr-Stubbs, M., Ganambarr, B., Maymuru, D. \& Sweeney, H. (2016) Co-becoming Bawaka: towards a relational understanding of place/space. Progress in Human Geography 40(4) 455-475. https://doi.org/10.1177/0309132515589437

Beaujeu-Garnier, J. \& Chabot, G. (1963) Traité de géographie urbaine. Colin, Paris.

Bendix, R. (2000) Heredity, hybridity and heritage from one fin de siècle to the next. In Anttonen, P.J., Siikala, A-L., Mathsien, S.R. \& Magnusson, L. (eds.) Folklore, heritage politics and ethnic diversity, 37-56. Multicultural Centre, Botkyrka.

Bennett, T. \& Joyce, P. (2010) Material powers: cultural studies, history and the material turn. Routledge, London.

Bereton, F., Bullock, C., Clinch, J.P. \& Scott, M. (2011) Rural change and individual well-being the case of Ireland and rural quality of life. European Urban and Regional Studies 18(2) 203-227. https://doi. org/ 10.1177/0969776411399346

Berman, M. (1983) All that is solid melts into air: the experience of modernity. Verso, London.

Biegańska, J., Grzelak-Kostulska, E., Dymitrow, M., Chodkowska-Miszczuk, J., Środa-Murawska, S. \& Rogatka, K. (2016) Młodzież z osiedli popegeerowskich a kształtowanie społecznych zasobów lokalnych [Youth of former State Agricultural Farm estates as local human resources]. Studia Obszarów Wiejskich [Rural Studies] 44 75-92. https://doi.org/ 10.7163/SOW.44.5

Bielewicz, E. (2016) Opatówek znów będzie miastem <http://www.gloswielkopolski.pl/wiadomosci/ wielkopolska/a/opatowek-znow-bedzie-miastem,9748254/> 17.04.2016.

Borcz, Z., Niedźwiecka-Filipiak, I. \& Zaniewska, H. (2009) Transformacje miasto wieś-wieś miasto. Uniwersytet Przyrodniczy, Wrocław.

Bosworth, G. \& Somerville, P. (eds) (2014) Interpreting rurality: multidisciplinary approaches. Routledge, London and New York.

Brauer, R. \& Dymitrow, M. (2014) Quality of life in rural areas: a topic for the rural development policy? Bulletin of Geography. Socio-Economic Series 25 25-54. https://doi.org/10.2478/bog-2014-0028

Brauer, R. \& Dymitrow, M. (2017) Human geography and the hinterland: the case of Torsten Hägerstrand's 'belated' recognition. Moravian Geographical Reports 2. (in press).

Braun, B. (2005) Environmental issues: writing a more-than-human urban geography. Progress in Human Geography 29(5) 635-650. https://doi.org/10.1191/0309132505ph574pr

Bryant, L. \& Pini, B. (2010) Gender and rurality. Routledge, New York.

Bukraba-Rylska, I. (2011) Czy wieś to „wieśniactwo”? Kultura Liberalna 128(24).

Bukraba-Rylska, I. \& Burszta, W. (eds) (2011) Stan i zróżnicowanie kultury wsi i małych miast w polsce: kanon i rozproszenie. Narodowe Centrum Kultury, Warsaw.

Campbell, G. (1999) The road to Kosovo: a Balkan diary. Westview Press, Boulder.

Castree, N., Chatterton, P.A., Heynen, N., Larner, W. \& Wright, M.W. (eds.) (2010) The point is to change it: Geographies of hope and survival in an age of crisis. Wiley-Blackwell, Oxford.

Champion, A. \& Hugo, G. (2004) New forms of urbanization: beyond the urban-rural dichotomy. Asghate, Hants.

[CIA] Central Intelligence Agency (2015) The World factbook 2014-15. Central Intelligence Agency, Langley.

Cloke, P. (2006a) Conceptualizing rurality. In Cloke, P., Marsden, T. \& Mooney, P.H. (eds.) Handbook of rural studies, 18-28. Sage, London.

Cloke, P. (2006b) Rurality and racialized others: out of place in the countryside? In Cloke, P., Marsden, T. \& Mooney, P.H. (eds.) Handbook of rural studies, 379-387. Sage, London.

Cloke, P. \& Johnston, R. (eds.) (2005) Deconstructing human geography's binaries, Sage, London, Thousand Oaks and New Delhi.

Cloke, P. \& Milbourne, P. (1992) Deprivation and lifestyles in rural Wales. Rurality and the cultural dimension. Journal of Rural Studies 8(4) 359-371. https://doi.org/10.1016/0743-0167(92)90050-G

Corbett, M. (2014) We have never been urban: modernization, small schools and resilient rurality in Atlantic Canada. The Journal of Rural and Community Development 9(3) 186-202.

Council of Ministers of the Republic of Poland (2005) Projekt Rozporzadzenia Rady Ministrów z dnia...........2005 r. w sprawie ustalenia granic niektórych gmin i miast oraz nadania miejscowościom statusu miasta. <https://bip. mswia.gov.pl/bip/projekty-aktow-prawnyc/2005/513,dok.htm/> 16.04.2017.

Cresswell, T. (2004) Discourse. In Kitchin, R. \& Thrift, N. (eds.) International encyclopedia of human geography 1, 211-214. Elsevier, London. 
Dahlberg, A. (2015) Categories are all around us: towards more porous, flexible, and negotiable boundaries in conservation-production landscapes. Norsk Geografisk Tidsskrift [Norwegian Journal of Geography] 69(4) 207-218. https://doi.org/10.1080/00291951.2015.1060258

Davies, N. (2011) Vanished kingdoms: the history of half-forgotten Europe. Penguin, London.

Dawidejt-Drobek, E. \& Drobek, W. (2015) Cultural aspects of urban restitution in Poland. In Krzysztofik, R. \& Dymitrow, M. (eds.) Degraded and restituted towns in Poland: origins, development, problems, 37-60. University of Gothenburg, Gothenburg.

Dębski, M., Nowak, A. \& Popow, M. (2010) Poland - a new reality, old problems. In Stocker, S. (ed.) European social watch report 2010: time for action - responding to poverty, social exclusion and inequality in Europe and beyond, 70-72. Eurostop, Brussels.

Dewey, R. (1960) The rural-urban continuum: real but relatively unimportant. American Journal of Sociology 66(1) 60-66.

Drobek, W. (1999) Rola miast zdegradowanych w sieci osadniczej Śląska. Państwowy Instytut Naukowy - Instytut Śląski w Opolu, Opole.

Drobek, W. (2004) Zmiany statusu administracyjnego lokalnych jednostek osadniczych. In Michałowski, S. \& Pawłowska, A. (eds.) Samorzqd lokalny w Polsce. Społeczno-polityczne aspekty funkcjonowania, 534-545. Uniwersytet Marii Curie-Skłodowskiej, Lublin.

Dymitrow, M. (2012) The hidden face of urbanity. Morphological differentiation of degraded and restituted towns in Poland in the context of the efficacy of the national administrative system. University of Gothenburg, Gothenburg.

Dymitrow, M. (2013) Degraded towns in Poland as cultural heritage. International Journal of Heritage Studies 19(7) 613-631. https://doi.org/10.1080/13527258.2012.681681

Dymitrow, M. (2014) The effigy of urbanity or a rural parody? A visual approach to small-town public space. Journal of Cultural Geography 31(1) 1-31. https://doi.org/10.1080/08873631.2013.873298

Dymitrow, M. (2015) Pojęcie miejskości w świetle reformy gminnej w Polsce międzywojennej [The concept of urbanity in light of the municipal reform of 1933-34 in interwar Poland]. In Krzysztofik, R. \& Dymitrow, M. (eds.) Degraded and restituted towns in Poland: origins, development, problems, 61-116. University of Gothenburg, Gothenburg.

Dymitrow, M. \& Brauer, R. (2014) Social deprivation and urbanity as the elephant in the room. In Efe, R., Onay, T.T., Sharuho, I. \& Atasoy, E. (eds.) Urban and urbanization, 381-395. St. Kliment Ohridski University Press, Sofia.

Dymitrow, M. \& Brauer, R. (2016) Land or people? On the iatrogenesis of conflation. Acta Geobalcanica 2(2) 63-75. https://doi.org/10.18509/AGB.2016.07

Dymitrow, M. \& Krzysztofik, R. (2015) Degradacja i restytucja jako pryzmaty pojęcia miejskości w kontekście jego formalnoprawnej zmienności [Degradation and restitution: Understanding the concept of urbanity through its oscillations within formal contexts]. In Krzysztofik, R. \& Dymitrow, M. (eds.) Degraded and restituted towns in Poland: origins, development, problems, 443-461. University of Gothenburg, Gothenburg.

Dymitrow, M. \& Stenseke, M. (2016) Rural-urban blurring and the subjectivity within. Rural Landscapes: Society, Environment, History 3(2) 1-13. https://doi.org/10.16993/rl.1

Dymitrow, M., Biegańska, J. \& Grzelak-Kostulska, E. (2017) Deprivation and the rural-urban trap. Tijdschrift voor economische en sociale geografie [online Feb 27 2017] https://doi.org/10.1111/ tesg. 12263

Easterlin, R.A., Angelescu, L. \& Zweig, J.S. (2011) The impact of modern economic growth on urbanrural differences in subjective well-being. World Development 39(12) 2187-2198. https://doi. org/10.1016/j.worlddev.2011.04.015

Eriksson, M. (2010) "People in Stockholm are smarter than countryside folks" - reproducing urban and rural imaginaries in film and life. Journal of Rural Studies 26(2) 95-104. https://doi.org/10.1016/j.jrurstud.2009.09.005

Erjavec, K. \& Erjavec, E. (2007) Changing EU agricultural policy discourses? The discourse analysis of Commissioner's speeches 2000-2007. Food Policy 34(2) 218-226. https://doi.org/10.1016/j. foodpol.2008.10.009

Essebo, M. (2013) Lock-in as make-believe. University of Gothenburg, Gothenburg.

European Commission (2008) Poverty and social exclusion in rural areas. Directorate-General for Employment, Social Affairs and Equal Opportunities, Brussels.

Feltynowski, M., Senetra, A., Biegańska, J., Grzelak-Kostulska, E., Dymitrow, M. \& Środa-Murawska, S. (2015) Some problems of local development: the example of former state agricultural farms in Poland. Research for Rural Development 2 237-243. 
Foucault, M. (1977) The confession of the flesh. In Gordon, C. (ed.) Power/knowledge: selected interviews and other writings 1972-1977, 194-228. Pantheon, New York.

Franklin, A. \& Crang, M. (2001) The trouble with tourism and travel theory. Tourist Studies 1(1) 5-22. https://doi.org/ 10.1177/146879760100100101

Frawley, R. (2014) Sarajevo Rose. Antigonish Review 179 47-53.

Freibach-Heifetz, D. \& Stopler, G. (2008) On conceptual dichotomies and social oppression. Philosophy and Social Criticism 34(5) 515-535. https://doi.org/10.1177/0191453708089197

Gajewski, M. (1964) Zmiany administracyjne miast i osiedli 1918-1963. GUS, Warsaw.

Gawryszewski, A. (2005) Ludność Polski w XX wieku. Instytut Geografii i Przestrzennego Zagospodarowania im. Stanisława Leszczyckiego, Warsaw.

Gibson-Graham, J.K. \& Roelvink, G. (2010) An economic ethics for the Anthropocene. In Castree, N., Chatterton, P.A., Heynen, N., Larner, W. \& Wright, M.W. (eds.) The point is to change it: geographies of hope and survival in an age of crisis, 320-346. Wiley-Blackwell, Oxford.

Gold, J.R. (2009) Modern city. In Kitchin, R. \& Thrift, N. (eds.) International encyclopedia of human geography 1,150-156. Elsevier, London.

Gorlach, K. \& Foryś, G. (2003) Key issues in rural-urban relations in Poland: between peasant past and European future. In Cristovao, A. \& Omodei Zorini, I. (eds.) Farming and rural systems research and extension, 289-298. ARSIA, Florence.

Gorman-Murray, A., Waitt, G. \& Gibson, C. (2012) Chilling out in 'cosmopolitan country': urban/rural hybridity and the construction of Daylesford as a 'lesbian and gay rural idyll'. Journal of Rural Studies 28(1) 69-79. https://doi.org/10.1016/j.jrurstud.2011.07.001

Graham, B., Ashworth, G.J. \& Tunbridge, J.E. (2000) A geography of heritage: power, culture and economy. Oxford University Press, Oxford.

Grossman, H. (1925) Struktura społeczna i gospodarcza Ks. Warszawskiego na podstawie spisów 1809-1810 roku. Kwartalnik Statystyczny 2(1) 1-108.

Grzegorczyk, P. (2009) Wąwolnica nie chce już dłużej być wsią. Moje Miasto Puławy. <http://www. mmpulawy.pl/artykul/wawolnica-nie-chce-juz-dluzejbyc-wsia> 14.07.2015.

Guba, E.G. \& Lincoln, Y.S. (1994) Competing paradigms in qualitative research. In Denzin, N.K. \& Lincoln, Y.S. (eds.) The SAGE handbook of qualitative research, 105-117. Sage, Thousand Oaks (CA).

Haack, S. (1996) Deviant logic, fuzzy logic: beyond the formalism. University of Chicago Press, Chicago.

Halamska, M. (2013)Wiejska Polska na początkuXXI wieku. Rozważania o gospodarce ispołeczeństwie. Scholar, Warsaw.

Halamska, M. (2014) Polska wieś na początku XXI wieku. Wszechnica. <http://wszechnica.org. pl/11/120/1007/polska wies na poczatku xxi wieku wywiad z prof maria halamska> 17.01.2016.

Halfacree, K.H. (1993) Locality and social representation: space, discourse and alternative definitions of the rural. Journal of Rural Studies 9(1) 23-37. https://doi.org/10.1016/0743-0167(93)90003-3

Halfacree, K. (2006) Rural space: constructing a three-fold architecture. Cloke, P., Marsden, T. \& Mooney, P.H. (eds.) Handbook of rural studies, 44-62. Sage, London.

Halfacree, K. (2009a) Rurality and post-rurality. In Kitchin, R. \& Thrift, N. (eds.) International encyclopedia of human geography 1, 449-456. Elsevier, London.

Halfacree, K. (2009b) Urban-rural continuum. In Kitchin, R. \& Thrift, N. (eds.) International encyclopedia of human geography 1, 119-124. Elsevier, London.

Hall, S. (ed.) (1997) Representation: cultural representations and signifying practices. Sage, London.

Hansen, K.P. (2011) Kultur und Kulturwissenschaft. A. Francke Verlag UTB, Tübingen.

Hidalgo Tenorio, E. (2011) Critical discourse analysis, an overview. Nordic Journal of English Studies 10 (1) $183-210$.

Hintikka, J. \& Tuomela, R. (1970) Towards a general theory of auxiliary concepts and definability in first-order theories. In Hintikka, J. \& Suppes, P. (eds.) Information and inference, 298-330. Springer, Dordrecht.

Hirsi Ali, A. (2016) Why don't feminists fight for Muslim women? Praeger University. <https://www. prageru.com/sites/default/files/courses/transcripts/ali-why dont feminists fight for muslim women-transcript $0 . p d f>$

Hoggart, K. (1990) Let's do away with rural. Journal of Rural Studies 6(3) 245-257. https://doi. org/10.1016/0743-0167(90)90079-N

Hubbard, P. (2006) City. Routledge, Abingdon and New York.

Hubbard, P., Kitchin, R., Bartley, B. \& Fuller, D. (2002) Thinking geographically: space, theory and contemporary human geography. Continuum, London.

Johnston, R.J. (1991) Geography and geographers. Arnold Publishing, London. 
Johnston, R. \& Sidaway, J.D. (2015) Have the human geographical can(n)ons fallen silent; or were they never primed? Journal of Historical Geography 49 49-60. https://doi.org/10.1016/j.jhg.2015.04.017

Jones, O. (2009) Nature-culture. In Kitchin, R. \& Thrift, N. (eds.) International encyclopedia of human geography 1, 309-323. Elsevier, London.

Journal of Law [Дневникъ Законовъ, Dziennik Praw] (1869) Vol. 69, № 235, 243, 244-253, 414-429, 460-473. Drukarnia Rządowa, Warsaw.

Journal of Law [Дневникъ Законовъ, Dziennik Praw] (1870) Krótka statystyka Gubernji Królestwa Polskiego obejmujqca rozległość i ludnośćtychże Gubernji oraz wykaz osad i gmin [Przedruk uzupełniony ze Skorowidza do Dziennika Praw, wydanego w połowie 1870 r.] 1870. Drukarnia Rządowa, Warsaw.

Kantor-Pietraga, I. (2014) Systematyka procesu depopulacji miast na obszarze Polski od XIX do XXI wieku. Wydawnictwo Uniwersytetu Śląskiego, Katowice.

Karpiniec, J. (1932) Ilość osad miejskich byłej Galicji i podział ich na miasta i miasteczka. In Bujak, F. \& Rutkowski, J. (eds.) Roczniki dziejów społeczno-gospodarczych vol. 2, 1-37. Kasa im. rektora J. Mianowskiego - Instytut Popierania Polskiej Twórczości Naukowe, Lviv.

Kegan, R. \& Lahey, L.L. (2009) Immunity to change: how to overcome it and unlock the potential in yourself and your organization. Harvard Business Press, Boston.

Kmita, G. (2014) Prawa miejskie dla Szczercowa. Twoja Okolica. <http://twojaokolica.pl/grzegorzkmita/ index.php/zdaniem-wojta/139-prawa-miejskie-dla-szczercowa> 26.05.2016.

Koch, A. (2005) Autopoietic spatial systems: the significance of actor network theory and system theory for the development of a system theoretical approach of space. Social Geography 1(1) 5-14. https://doi.org/10.5194/sg-1-5-2005

Kołodziejczyk, R. [1961] (1979) Zamiana miast na osady w Królestwie Polskim. In Kołodziejczyk, R. (ed.) Miasta, mieszczaństwo, burżuazja w Polsce w XIX w. Szkice i rozprawy historyczne, 52-66. Państwowe Wydawnictwo Naukowe, Warsaw.

Kommisyja dla Miast (1825) Wykaz Miast w Królstwie Polskiem na wieyskie osady zamienionych od dn. 1 lutego 1820 r., to iest od daty ustanowienia Kommissyi dla Miast 1825. Akta Komisji Rzq̨dowej Spraw Wewnętrznych 201(44). Archiwum Główne Akt Dawnych, Warsaw.

Konecka-Szydłowska, B. (2015) Restituted towns and their socio-economic conditions for development. In Krzysztofik, R. \& Dymitrow, M. (eds.) Degraded and restituted towns in Poland: origins, development, problems, 117-138. University of Gothenburg, Gothenburg.

Koszutski, S. (1915) Nasze miasta a samorząd. Życie miast w Królestwie Polskim i reforma samorzqdowa. E. Wende i Spółka, Warsaw and Lviv.

Koter, M. (1999) Za jakim modelem podziału terytorialnego Polski opowiedzieć się? Wnioski z doświadczeń z przeszłości oraz wzorców europejskich. Acta Universitatis Lodziensis - Folia Geographica Socio-Oeconomica 1 7-29.

Krzysztofik, R. (2014) Geneza aglomeracji miast na obszarze Polski. Wydawnictwo Uniwersytetu Sląskiego, Katowice.

Krzysztofik, R. \& Dymitrow, M. (eds.) (2015a) Miasta zdegradowane i restytuowane w Polsce. Geneza, rozwój, problemy [Degraded and restituted towns in Poland: origins, development, problems]. University of Gothenburg, Gothenburg.

Krzysztofik, R. \& Dymitrow, M. (2015b) Miasta zdegradowane i restytuowane. Istota problemu i zakres badań [Research on degraded and restituted towns: overview and state-of-the-art]. In Krzysztofik, R. \& Dymitrow, M. (eds.) Degraded and restituted towns in Poland: origins, development, problems, 1-36. University of Gothenburg, Gothenburg.

Krzysztofik, R., Dymitrow, M., Kantor-Pietraga, I. \& Spórna, T. (2016) The concept of urban hibernation. European Planning Studies 24(2) 316-343. https://doi.org/10.1080/09654313.2015.1078296

Krzysztofik, R., Dymitrow, M., Szmytkie, R., Kantor-Pietraga, I., Pełka-Gościniak, J. \& Spórna, T. (2015) Environmental hazards and urban abandonment: case studies and typological issues. Geografiska Annaler: Series B, Human Geography 97(4) 291-308. https://doi.org/10.1111/geob.12082

Krzysztofik, R., Dymitrow, M., Biegańska, J., Senetra, A., Gavriilidou, E., Nadolu, B., Kantor-Pietraga, I., Grzelak-Kostulska, E., Oureilidou, E., Luches, D., Spórna, T., Teodorescu, D., WasilewiczPszczółkowska, M., Holmertz, G. \& Szczepańska, A. (2017a) Landscapes with different logics: a physicalist approach to semantic conflicts in spatial planning. Quaestiones Geographicae 35(4). (in press).

Krzysztofik, R., Dymitrow, M., Grzelak-Kostulska, E. \& Biegańska, J. (2017b) Poverty and social exclusion: an alternative spatial explanation. Bulletin of Geography. Socio-Economic Series 35 4564. https://doi.org/10.1515/bog-2017-0004

Kubicki, P. (2011) Miasto i wieś. Krótka historia toksycznej miłości. Kultura Liberalna 128(24). 
Kudra, A. (2014) Jak zostać miastem? Prawo Dla Samorzadu. 21.07.2014.

Kurtz, M. \& Craig, V. (2009) Constructing rural geographies in publication. ACME: An International E-Journal for Critical Geographies 8 376-393.

Latour, B. (2013) An inquiry into modes of existence. Harvard University Press, Cambridge.

Law, J. (2004) After method: mess in social science research. Routledge, Abingdon and New York.

Law, J. \& Urry, J. (2004) Enacting the social. Economy and Society 33(3) 390-410. https://doi. org/10.1080/0308514042000225716

Lawson, V., Jarosz, L. \& Bonds, A. (2008) Building economies from the bottom up: (Mis)representations of poverty in the rural American Northwest. Social \& Cultural Geography 9(7) 737-753. https://doi. org/10.1080/14649360802382354

Lee, K-Y. (2002) System transformation in Poland since 1989. Research Series on International Affairs, Sogang.

Lees, L. (2004) Urban geography: discourse analysis and urban research. Progress in Human Geography 28(1) 101-107. https://doi.org/10.1191/0309132504ph473pr

Leuzinger-Bohleber, M. (2004). What does conceptual research have to offer? International Journal of Psychoanalysis 85(5) 1477-1478. https://doi.org/10.1516/TABK-E55U-D6J6-YWCY

Leyshon, M. (2008). The betweenness of being a rural youth: inclusive and exclusive lifestyles. Social \& Cultural Geography 9(1) 1-26. https://doi.org/ 10.1080/14649360701789535

Lincoln, Y.S., Lynham, S.A. \& Guba, E.G. (2011) Paradigmatic controversies, contradictions, and emerging confluences, revisited. In Denzin, N.K. \& Lincoln, Y.S. (eds.) The SAGE handbook of qualitative research, 97-128. SAGE, Los Angeles, London, New Delhi, Singapore and Washington.

Little, J. (1999) Otherness, representation and the cultural construction of rurality. Progress in Human Geography 23(3) 437-442. https://doi.org/10.1177/030913259902300307

Łopata, T. (2016) Korzyści - czyli co możemy zyskać, będąc miastem. Gmina Lanckorona. <http://www. lanckorona.pl/> 26.05.2016.

Lubecka, A. (2010) Rewitalizacja/gentryfikacja jako element zmieniający semantykę miasta. In Skalski, K. (ed.) O budowie metod rewitalizacji w Polsce - aspekty wybrane, 157-173. Uniwersytet Jagielloński. Kraków.

Margolis, E. \& Laurence, S. (eds.) (1999) Concepts: core readings. MIT Press, Cambridge.

Maxwell, J.A. (2013) Qualitative research design: an interactive approach. SAGE, Los Angeles, London, New Delhi, Singapore and Washington.

Mazurkiewicz, J. (1967) Likwidacja ustroju miejskiego mniejszych miast w Księstwie Warszawskim i Królestwie Polskim w okresie przed masową zamianą miast na osady (1807-1864). Rocznik Lubelski 10 211-228.

Meindl, J.R. \& Lerner, M.J. (1983) The heroic motive: some experimental demonstrations. Journal of Experimental Social Psychology 19(1) 1-20. https://doi.org/10.1016/0022-1031(83)90002-1

Mielcarek, A.J. (2008) Podziały terytorialno-administracyjne II Rzeczypospolitej w zakresie administracji zespolonej. Neriton, Warsaw.

Mihaylov, V. (2014) Consciousness and identity of human communities in a geospatial dimension: an interdisciplinary sphere of developing ideas, approaches and research perspectives. In Mihaylov, V. (ed.) Territories and identities in central, eastern and southeastern Europe, 19-36. Instytut Geopolityki, Częstochowa.

Mikołajek, N. (2012) Część gmin, powiatów i województw do likwidacji? Niedługo to konieczność. Polityka. 29.11.2012.

Millward, H., Harrington, L., Ilbery, B. \& Beesley, K. (2003) Milieux, viewpoints \& processes of change in the new countryside. In Beesley, K., Millward, H. \& Harrington, L. (eds.) The new countryside, 9-23. Brandon University, Brandon.

Ministry of Labour and Social Policy (2006) Social exclusion and integration in Poland. An indicatorsbased approach. UNDP, Warsaw.

Miszewska, B. (2007) Recovered cities. Bulletin of Geography. Socio-Economic Series 7 31-42.

Munkejord, M.C. (2011) Reinventing rurality in the north. In Viken, A. \& Nyseth, T. (eds.) Place reinvetions, Northern perspectives, 203-221. Ashgate, Surrey.

Munslow, A. (2006) Deconstructing history. Routledge, London and New York.

Murdoch, J. (2003) Co-constructing the countryside: hybrid networks and the extensive self. In Cloke, P. (ed.) Country visions, 263-282. Pearson Education Ltd, Harlow.

Murphy, K. (2010) Fears and fantasies: modernity, gender and the rural-urban divide. Peter Lang, Bern.

Murzyn, M. \& Gwosdz, K. (2003) Dilemmas encountered in the development of tourism in a degraded town. The case of Chełmsko Ślaskie (Schönberg) in Lower Silesia. In Kurek, W. (ed.) Issues of tourism and health resort management, 183-200. Uniwersytet Jagielloński, Kraków. 
Nietyksza, M. (1986) Rozwój miast i aglomeracji miejsko-przemysłowych w Królestwie Polskim 18651914. Państwowe Wydawnictwo Naukowe, Warsaw.

Nietzsche, F. [1878] (1996) Human, all too human: a book for free spirits. Translated by R.J. Hollingdale. Cambridge University Press, Cambridge.

Nilsson, B. \& Lundgren, A.S. (2015) Logics of rurality: political rhetoric about the Swedish North. Journal of Rural Studies 37 85-95. https://doi.org/10.1016/j.jrurstud.2014.11.012

Otok, S. (2009) Geografia polityczna - geopolityka, ekopolityka, globalistyka. Wydawnictwo Naukowe PWN, Warsaw.

Pacione, M. (2009) Urban geography. A global perspective. Routledge, London.

Panelli, R. (2010) More-than-human social geographies: post-human and other possibilities. Progress in Human Geography 34(1) 79-87. https://doi.org/10.1177/0309132509105007

Pavković, A., Koscharsky, H. \& Czarnota, A. (eds.) (1995) Nationalism and post-communism: a collection of essays. Dartmouth, Aldershot and Hants.

Pennebaker, J.W. \& Banasik, B.L. [1997] (2008) On the creation and maintenance of collective memories: history as social psychology. In Pennebaker, J.W., Paez, D. \& Rimé, B. (eds.) Collective memory of political events: a social psychological perspective, 3-19. Psychology Press, New York.

Pile, S. (1999) What is a city? In Massey, D., Allen, J. \& Pile, S. (eds.) City worlds, 3-53. Routledge, New York.

Plucińska, S. (2009) Pawłowice nie chcą być miastem. Dziennik Zachodni 27.07.2009. <http://www. dziennikzachodni.pl/artykul/146111,pawlowice-nie-chca-byc-miastem, id,t.html> 18.01.2017.

Pobrić, A. \& Robinson, G.M. (2015) Population ageing and low fertility: recent demographic changes in Bosnia and Herzegovina. Journal of Population Research 32(1) 23-43. https://doi.org/10.1007/ s12546-014-9141-5

Przesmycka, E. (2015) Degraded and restituted towns of the Lublin region and their spatioarchitectural transformations. In Krzysztofik, R. \& Dymitrow, M. (eds.) Degraded and restituted towns in Poland: origins, development, problems, 209-248. University of Gothenburg, Gothenburg.

Radoszyce Municipality (2016) Uchwała Nr XX/115/2016 Rady Gminy Radoszyce z dnia 27 września 2016 roku w sprawie wystąpienia z wnioskiem o nadanie statusu miasta miejscowości Radoszyce $<$ http://www.biuletyn.net/nt-bin/ private/radoszyce/5075.pdf> 15.04.2017.

Rapport, N. \& Overing, J. (2014) Social and cultural anthropology: the key concepts. Routledge, New York.

Remont, R. (2016) Widuchowa nie chce już wójta? Rządzić może burmistrz. <http://ono24.info/ widuchowa-nie-chce-juz-wojta-rzadzic-moze-burmistrz,a2033> 16.12.2016.

Riding, J. \& Wake-Walker, J. (2017) Towards a cultural geopolitics: on the making of a documentarypoetry film about a post-conflict place. Fennia 195(1) 61-84. https://doi.org/10.11143/fennia.60213

Rodecki, F.B. (1830). Obraz jeograficzno-statystyczny Królestwa Polskiego. Drukarnia Antoniego Gałęzowskiego i Kompanii, Warsaw.

Rynek Pracy (2016) Pracujący w rolnictwie, przemyśle i usługach. Rynek Pracy. <http://rynekpracy. org/x/989321> 17.07.2016.

Rytkönen, P. (2014) Constructing the new rurality - challenges and opportunities (of a recent shift?) in Swedish rural policies. International Agricultural Policy 2 7-19.

Saltzman, K., Head, L. \& Stenseke, M. (2011) Do cows belong in nature? The cultural basis of agriculture in Sweden and Australia. Journal of Rural Studies 27(1) 54-62. https://doi.org/10.1016/j. jrurstud.2010.09.001

Schaffer, B. (1978) Administrative legacies and links in the postcolonial state: preparation, training and administrative reform. Development and Change 9(2) 175-200. https://doi. org/10.1111/j.1467-7660.1978.tb00759.x

Schwartz, S. (2005) Sarajevo rose: a Balkan Jewish notebook. Saqi, London.

Scott, A., Gilbert, A. \& Gelan, A. (2007) The urban-rural divide? Myth or reality? Macaulay Institute, Aberdeen.

Sejm of the Republic of Poland (2003) Ustawa z dnia 29 sierpnia 2003 r. o urzędowych nazwach miejscowości i obiektów fizjograficznych 2003. Dziennik Ustaw 166(1612) 1-8.

Shubin, S. (2007) Networked poverty in rural Russia. Europe-Asia Studies 59(4) 591-620. https://doi. org/10.1080/09668130701289935

Sidorenko, E. (2008) Which way to Poland? Re-emerging from Romantic unity. In Myant, M. \& Cox, T. (eds.) Reinventing Poland. Economic and political transformation and evolving national identity, 100115. Routledge, Abingdon.

Siemiński, J. (2000) Byłe (zdegradowane) miasteczka w Polsce. Przestrzeń. Informator Planowania Przestrzennego 11(2) 14-22. 
Soja, E. \& Hooper, B. (1993) The spaces that difference makes: some notes on the geographical margins of the new cultural politics. In Keith, M. \& Pile, S. (eds.) Place and the politics of identity, 183-205. Routledge, London.

Sokołowski, D. (2002) Nowe nadania praw miejskich w Polsce. Promocje Kujawsko-Pomorskie 8(10) 16.

Sokołowski, D. (2011) Miasta zdegradowane w woj. kujawsko-pomorskim. In Marciniak, K., Sikora, K. \& Sokołowski, D. (eds.) Conceptions and research problems of geography, 363-379. Totem, Bydgoszcz.

Sokołowski, D. (2015) Functional differentiation of degraded and restituted towns to the background of other similarly sized towns and villages in Eastern Poland. In Krzysztofik, R. \& Dymitrow, M. (eds.) Degraded and restituted towns in Poland: origins, development, problems, 249-271. University of Gothenburg, Gothenburg.

Śpiewak, R. (2012) Definiowanie kategorii „wieś” na początku XXI wieku, czyli o kłopotach badacza obszarów wiejskich. Wieś i Rolnictwo 156(3) 30-46.

Spórna, T., Krzysztofik, R. \& Dymitrow, M. (2015a) Miasta zdegradowane i restytuowane na mapach [Degraded and restituted towns on maps]. In Krzysztofik, R. \& Dymitrow, M. (eds.) Degraded and restituted towns in Poland: origins, development, problems, 423-442. University of Gothenburg, Gothenburg.

Spórna, T., Krzysztofik, R. \& Dymitrow, M. (2015b) Miasta zdegradowane i restytuowane w liczbach [Degraded and restituted towns in numbers]. In Krzysztofik, R. \& Dymitrow, M. (eds.) Degraded and restituted towns in Poland: origins, development, problems, 367-422. University of Gothenburg, Gothenburg.

Stenbacka, S. (2011) Othering the rural: about the construction of rural masculinities and the unspoken urban hegemonic ideal in Swedish media. Journal of Rural Studies 27(3) 235-244. https://doi.org/10.1016/j.jrurstud.2011.05.006

Strzemińska, A. (2011) Ani miejscy, ani wiejscy. Pracujący. Kultura Liberalna 128(24)

Szmytkie, R. (2015) Degraded towns in Poland as potentially new towns. In Krzysztofik, R. \& Dymitrow, M. (eds.) Degraded and restituted towns in Poland: origins, development, problems, 295-318. University of Gothenburg, Gothenburg.

Szmytkie, R., Krzysztofik, R., Dymitrow, M., Kantor-Pietraga, I., Pełka-Gościniak, J., Spórna, T. \& Brauer, R. (2015) Miasta zdegradowane a procesy opustoszania [Degraded towns and urban abandonment]. In Krzysztofik, R. \& Dymitrow, M. (eds.) Degraded and restituted towns in Poland: origins, development, problems, 185-207. University of Gothenburg, Gothenburg.

Szturm de Sztrem, E. (1925) Charakter prawny miast w województwach wschodnich b. dzielnicy rosyjskiej. Kwartalnik Statystyczny 2(1) 217-221.

Szymańska, D. (2013) Geografia osadnictwa. Wydawnictwo Naukowe PWN, Warsaw.

Taras, R. (2010) Russophobia in Poland? National fears and the effects on EU relations with the Russian Federation. European International Studies Association. <http://www.eisa-net.org/bebruga/eisa/files/events/stockholm/Taras.SGIR.Russia.pdf> 14.09.2016

Tribe, J. \& Liburd, J.J. (2016) The tourism knowledge system. Annals of Tourism Research 57 44-61. https://doi.org/10.1016/j.annals.2015.11.011

TVP Lublin (2015) Czy wieś Siedliszcze zostanie miastem? TVP Lublin. < http://lublin.tvp.pl/19256808/ czy-wies-siedliszcze-zostanie-miastem> 09.07.2015.

Vlahov, D. \& Galea, S. (2002) Urbanization, urbanicity, and health. Journal of Urban Health 79(4) S1S12. https://doi.org/10.1093/jurban/79.suppl 1.S1

Waitt, G.R. (2005) Doing discourse analysis. In Hay, I. (ed.) Qualitative research methods in human geography, 163-191. Oxford University Press, Oxford.

Williams, M.L., Bowen, A.M. \& Horvath, K.J. (2005) The social/sexual environment of gay men residing in a rural frontier state: implications for the development of HIV prevention programs. The Journal of Rural Health 21(1) 48-55. https://doi.org/10.1111/j.1748-0361.2005.tb00061.x

Williams, R. (1975) The country and the city. Oxford University Press, Oxford.

Winther Jørgensen, M. \& Phillips, L.J. (2002). Discourse analysis as theory and method. Sage, London.

Wójcik, M. (2013) Obszary versus miejsca, czyli o przestrzennych formach interpretacji przemian polskiej wsi. Studia Obszarów Wiejskich 34 9-22.

Woods, M. (2010a) Rural. Routledge, New York.

Woods, M. (2010b) Performing rurality and practising rural geography. Progress in Human Geography 34(6) 835-846. https://doi.org/10.1177/0309132509357356

Woodward, R. (1996) 'Deprivation' and 'the rural': an investigation into contradictory discourses. Journal of Rural Studies 12(1) 55-67. https://doi.org/10.1016/0743-0167(95)00048-8 
Wren, D.A. \& Bedeian, A.G. (2009) The evolution of management thought. $6^{\text {th }}$ edition. Wiley, Hoboken. Wright, J.K. (1947) Terræ Incognitæ: the place of imagination in geography. Annals of the Association of American Geographers 37 1-15. https://doi.org/10.1080/00045604709351940

Xin, S., Tribe, J. \& Chambers, D. (2013) Conceptual research in tourism. Annals of Tourism Research 41 66-88. https://doi.org/ 10.1016/j.annals.2012.12.003

Zaniewska, H., Thiel, M. \& Dąbkowski, N. (2015) Creating a new identity for small restituted towns some problems. In Krzysztofik, R. \& Dymitrow, M. (eds.) Degraded and restituted towns in Poland: origins, development, problems, 319-346. University of Gothenburg, Gothenburg.

Zaremba, M. (2016) Den uträknade polackens revansch. Dagens Nyheter. 20.02.2016.

Zieliński, S. (1913) Mapa bitew i potyczek 1863-1864 w Królestwie Kongresowym z datami starć. Fundusz Wydawniczy Muzeum Narodowego, Rapperswil. 